\title{
CIÊNCIA JURÍDICA EM FORMAÇÃO: O PERFIL DOS EGRESSOS DA ÁREA DE DIREITO ADMINISTRATIVO (PPGD-USP, 1989-2020) ${ }^{1}$
}

\author{
Marco Antônio Moraes Alberto ${ }^{2}$
}

Introdução

O programa de pós-graduação em Direito da Universidade de São Paulo (USP) completa, em 2021, cinquenta anos ininterruptos, contados a partir das diretrizes elaboradas pelo Parecer Sucupira. Não é pouco. A experiência de meio século o torna, no plano da ciência jurídica, o programa mais antigo do país, e o que mais contribuiu, de um ponto de vista estritamente histórico e quantitativo, para a formação de quadros de ensino e pesquisa no campo jurídico brasileiro. Visto em perspectiva, o percurso institucional do programa se confunde com a própria história recente do Direito brasileiro.

Em uma área como a de Direito administrativo, ${ }^{3}$ que constitui o estudo de caso deste artigo, o fenômeno é ainda mais palpável, e vem refletido na relação entre o programa de pós-graduação e a construção de uma nova ordem constitucional, a partir da transição democrática brasileira. Daí a premissa desta pesquisa, de que o perfil de egressos constitui variável relevante e mensurável da participação do programa na construção de uma "ciência jurídica" propriamente nacional, e da influência da conjuntura social sobre o ensino e a pesquisa do Direito.

\footnotetext{
1 Agradeço ao Professor Fernando Dias Menezes de Almeida, que, não se limitando a permitir que seu levantamento fosse amplamente utilizado na construção dessa pesquisa, deu também todo o estímulo necessário e a interlocução sempre amiga para que as minhas ideias pudessem se transformar neste artigo. De igual maneira, agradeço ao Professor Conrado Hubner Mendes, à Professora Danielle Hanna Rached, a Daniel Peixoto Murata e a Juliana Pacetta Ruiz, por conversas proveitosas que me conduziram a este trabalho. Pela leitura de versões preliminares deste capítulo, e pela viabilização de sua publicação, agradeço igualmente ao Professor Fernando Facury Scaff e à Professora Ana Elisa Bechara. Por fim, mas não menos importante, sou grato ao Professor Vitor Rhein Schirato, pela orientação do meu doutorado e pelo apoio integral de sempre, e à FAPESP, pelo financiamento do meu atual projeto de pesquisa (Processo $\left.n^{\circ} 2017 / 13539\right)$.

2 Doutorando em Direito do Estado pela Universidade de São Paulo (FDUSP). Pesquisador em tempo integral e bolsista da Fundação de Amparo à Pesquisa do Estado de São Paulo (FAPESP). Coordenador do Grupo de Estudos sobre a Legalidade da Universidade de São Paulo (GELEG-USP). Foi Representante Discente na Comissão de Pesquisa da FDUSP (2018-2020). É Representante Discente no Departamento de Filosofia e Teoria Geral do Direito desde 2017 (até 2021), e na Comissão de Pós-Graduação da FDUSP desde 2019 (até 2021).

3 Para usar de rigor, "Direito Administrativo" é, no programa de pós-graduação em direito da USP, uma subárea da área "Direito do Estado". No entanto, nesta pesquisa, fez-se recorte formal restrito à "subárea" de "Direito Administrativo", de modo a ser empiricamente indiferente, aqui, a existência da "área de Direito do Estado" (da qual participam, junto a subárea de direito administrativo, as subáreas "direito constitucional" e "teoria do Estado"). Em razão disso, e para evitar confusões aos leitores menos acostumados com a complexidade da pós-graduação em direito da USP, irei sempre me referir, neste texto, à "área de Direito Administrativo", ainda que ela seja, do ponto de vista regimental, uma "subárea".
} 
Mapear o perfil profissional dos egressos do programa tem, assim, conteúdo semântico de "formação", revelando uma direção a ser percorrida em seus dois sentidos: a formação da ciência jurídica nacional a partir do ensino e da pesquisa em Direito, e a formação de profissionais do Direito a partir da estrutura social, política e intelectual brasileira.

É, contudo, lugar-comum da sociologia jurídica latino-americana o argumento de que não existe clareza sobre a formação de profissionais do Direito. As causas da obscuridade seriam abundantes: a falta de reflexão sobre quem o ensino jurídico tem a pretensão de formar; ${ }^{4}$ a vasta difusão de experiências e modalidades de pós-graduação, no contexto de uma graduação que se torna cada vez mais insuficiente para o acesso ao mercado jurídico de ponta; 5 a sobrevivência de uma "cultura jurídica tradicional", "ortodoxa e ultrapassada", que impediria que interesses avançassem na reformulação do ensino jurídico; ${ }^{6}$ a falta de políticas públicas consistentes e sistemáticas; ${ }^{7}$ a confusão entre ensino "manualista" e pesquisa científica; ${ }^{8}$ a multiplicidade de papéis, nem sempre conciliáveis, que as universidades são convocadas a exercer nas sociedades latino-americanas, marcadas por desigualdades sociais estruturais e historicamente persistentes. ${ }^{9}$

Um bom ponto de partida, senão para resolver, ao menos para compreender e equacionar essa infinidade de problemas, pode ser o do conhecimento empírico dos dados envolvidos. Todo diagnóstico metodologicamente consistente deve partir de dados, e é a isto que o presente artigo se propõe. Fornecer dados para futuros diagnósticos. Dando um passo para trás em relação às hipóteses acima mencionadas, este trabalho tem o objetivo de investigar o perfil profissional dos egressos do programa de pósgraduação em Direito da Universidade de São Paulo. De que se ocupam depois da defesa de suas teses e dissertações? O que adquirem - e para que meios profissionais levam - o

4 GHIRARDI, José Garcez. O instante do encontro: questões fundamentais para o ensino jurídico. São Paulo: FGV, 2012, p. 48.

5 BERGOGLIO, María Inez. Cambios en la profesión jurídica en América Latina. Revista sobre enseñanza del derecho, v. 10, 2007, p. 13.

6 FARIA, José Eduardo Campos de Oliveira. Ensino e pensamento jurídico. In: Baú de ossos de um sociólogo do direito. Curitiba: Juruá, 2018, p. 40.

7 CHIROLEU, Adriana. La educación superior em América Latina: ¿Problemas insolubles o recetas inadecuadas? Revista Avaliação, v. 16, 2011, p. 649.

$8 \quad$ AFONSO DA SILVA, Virgílio. Debates - o que é pesquisa em direito? In: $O$ que é pesquisa em direito? (VV.AA.). São Paulo: Quartier Latin, 2005, p. 61.

9 BRUNNER, José Joaquín; BALÁN, Jorge; COURARD, Hernán; COX, Cristián; DURHAM, Eunice; FANELI, Ana María García de; KENT, Rollin; KLEIN, Lúcia; LUCIO, Ricardo; SAMPAIO, Helena; SERRANO, Mariana; SCHWARTZMAN, Simon. Educación superior em América Latina: una agenda de problemas, políticas y debates en el umbral del año 2000 - proyecto de políticas comparadas de educación superior. Bogotá: Nacional, 1995, p. 3. 
conhecimento que desenvolveram junto ao programa? Como (e quantos) se envolvem com docência? E, se o fazem, junto a que tipo de instituição de ensino?

Com essa série de questões, busca-se não apenas um "repositório de dados", mas uma investigação da própria difusão social do programa. Em quais meios jurídicos o programa surte mais efeito? Em que medida o programa exercita algo como uma vocação de "formação docente"? Perguntas, portanto, que transcendem trajetórias de formação individual, e que, no agregado, constituem variáveis relevantes para a própria autoconstrução do programa de pós-graduação.

Para tentar responder a essas perguntas, o artigo propõe um estudo de caso a partir do universo de egressos da área de Direito Administrativo, tendo como horizonte temporal um período de 32 anos que coincide com o "pós-88" (1989-2020).

Além da introdução e da conclusão, o artigo se compõe de um tópico metodológico (seção 1), um tópico de contextualização do estudo empírico (seção 2), e de três seções de apresentação e análise de dados, que cuidam, em sequência, da visão geral do perfil dos egressos (seção 3), do detalhamento desse perfil por título e por período de tempo (seção 4), e da integração dos egressos a atividades de docência (seção 5).

\section{Metodologia}

Antes de avançar, é preciso fazer uma breve explicação metodológica. Não é usual, no Brasil, a mensuração do perfil de egressos das instituições de ensino superior (IES), seja no âmbito de graduação, seja no de pós-graduação. De uma maneira geral, mapeamentos desse tipo são realizados enquanto o discente ainda está vinculado à instituição de ensino, o que visa a subsidiar decisões de gestão universitária. Por outro lado, também têm sido cada vez mais comuns as abordagens do histórico pessoal de alunas e alunos ingressantes, o que têm contribuído significativamente para estudos de natureza socioeconômica e étnico-cultural. Políticas públicas incrementais - como políticas afirmativas e de equidade de gênero - são desenhadas a partir desse tipo de informação. ${ }^{10} \mathrm{O}$ que dizer, no entanto, do acompanhamento de egressos?

O caráter relativamente recente da pós-graduação no Brasil ajuda a explicar a aparente escassez de dados a esse respeito, ao menos no que se refere à pós-graduação

10 Para ficar em apenas dois exemplos, citem-se o estudo "A ação afirmativa no ensino superior brasileiro", elaborado em 2011 pelo Grupo de Estudos Multidisciplinares das Ações Afirmativas da Universidade de São Paulo (GEMAA), que foi a base para o posterior desenvolvimento, pelo Conselho Universitário, do sistema de cotas da USP, e a pesquisa coletiva "Interações de gênero nas salas de aula da Faculdade de Direito da USP: um currículo oculto?”, publicada em 2019 pela Cátedra UNESCO de Direto à Educação da Universidade de São Paulo (USP), que tem fomentado o debate sobre equidade de gênero em todas as instâncias de ensino, deliberação e pesquisa da Faculdade de Direito da USP. 
em Direito. ${ }^{11}$ A dificuldade em manter contato com os antigos discentes, após o término de seu vínculo com as instituições de ensino superior, é também um problema prático importante. ${ }^{12}$ Mas, seja como for, os obstáculos em perfilar egressos não são aleatórios. Faltam dados consolidados, e os que existem não se encontram em bases sistematizadas e confiáveis.

Uma exceção, no interior desse cenário pouco convidativo, aparece na obra "Formação da teoria do Direito Administrativo no Brasil", de Fernando Dias Menezes de Almeida, escrita em 2013 e publicada dois anos mais tarde. ${ }^{13}$ Não se trata exatamente de um levantamento de egressos, mas sim de um mapeamento de todas as teses e dissertações em Direito Administrativo apresentadas junto ao programa de pós-graduação em Direito da Universidade de São Paulo, entre 1988 e 2012. É natural, entretanto, que um levantamento desse tipo envolva os egressos, na medida em que teses e dissertações concluídas em um programa de pós-graduação constituem um marcador eficiente dos egressos desse programa. Em todo e qualquer programa de pós-graduação, quem defende - com êxito - uma tese ou dissertação se torna, automaticamente, egresso.

E foi esse o ponto de partida que animou a construção da metodologia do presente trabalho. Enquanto ângulo metodológico, partir do universo de teses e dissertações pareceu uma estratégia consistente para, a um só tempo, evitar recortes amostrais arbitrários e compensar a ausência de uma base de dados sistematizada de egressos.

A recorrência a um estudo de caso, concentrando o levantamento em uma área específica do programa - Direito Administrativo - não é casual. Ela não se dá apenas por preferências pessoais ou mesmo afetivas do autor. Trata-se do recorte proposto pelo aludido trabalho de Fernando Dias Menezes de Almeida, que não é só a base de inspiração da presente pesquisa, mas também a plataforma empírica onde ela se encontra sedimentada. Ademais, sendo uma área na qual - disclaimer - o autor tem trabalhado nos últimos seis anos, é natural que ele encontre maior facilidade e familiaridade no levantamento de dados internos a esse recorte.

Como foi dito, o universo de teses e dissertações oferece um ponto de partida para conhecermos o egresso: seu nome, o título de sua tese (ou dissertação), o nome de seu orientador(a) e o ano em que defendeu seu trabalho (logo, o ano em que se

11 O programa de pós-graduação em direito mais antigo do Brasil é precisamente o da Universidade de São Paulo, instituído em 1970.

12 Uma solução para essa dificuldade prática tem sido a instituição de associações voluntárias de ex-alunos, à inspiração do que acontece na experiência norte-americana. O "Alumni USP" e a "Associação de Antigos Alunos da Fundação Arcadas" são exemplos de iniciativas desse tipo.

13 ALMEIDA, Fernando Dias Menezes de. Formação da teoria do direito administrativo no Brasil. São Paulo: Quartier Latin, 2015, p. 377-390. 
tornou egresso). O propósito desta pesquisa é aprofundar o conhecimento destes egressos, pesquisando sua posição no universo das profissões jurídicas. Que tipo de trabalho ele exercem após concluírem o programa? Como se apropriam dos conhecimentos ali adquiridos? Em quais setores do mercado jurídico o programa surte mais efeito?

Para tanto, foram organizadas duas grandes matrizes com o universo de teses e dissertações. Essas matrizes, em pesquisa linha a linha, deram o parâmetro para a investigação das ocupações profissionais dos egressos.

A primeira matriz - ANEXO 1 - é composta do universo de teses e dissertações defendidas na área de Direito Administrativo entre 1988 e 2012. Ela foi adaptada a partir do levantamento constante da já citada obra de Fernando Dias Menezes de Almeida. Na próxima seção deste capítulo, detalharei em que consistiu essa adaptação.

A segunda matriz - ANEXO 2 - é composta do universo de teses e dissertações defendidas na área de Direito Administrativo entre 2013 e 2020. Optei por atualizar o levantamento de Fernando Dias Menezes de Almeida, buscando por conta própria os dados necessários ao seu prolongamento até o ano de 2020. Mantive, contudo, os mesmos critérios de pesquisa da primeira matriz - nome do aluno(a), título da tese ou dissertação, nome do orientador(a) e ano de defesa.

As informações constantes nas matrizes - ANEXOS 1 e 2 - são públicas, o que autoriza sua reprodução integral neste trabalho. Foram utilizadas as bases da Universidade de São Paulo e, quando necessário, recorreu-se à análise manual de currículos e registros de biblioteca.

Já as informações de segunda ordem, que constituem a novidade da presente pesquisa, foram pesquisadas primeiramente em currículos abertos ao público (Lattes, ORCid, Fapesp, etc.) e, subsidiariamente, em plataformas digitais (sítios eletrônicos oficiais, de tribunais, de procuradorias, de órgãos de governo, do Ministério Público, etc., e sítios eletrônicos profissionais, de instituições de ensino superior e escritórios de advocacia). Como medida de proteção de dados, e em respeito à privacidade dos egressos, essas informações não serão aqui divulgadas individualmente, e não constam das matrizes anexas. As informações que serão expostas nas próximas seções tratam desses dados sempre de maneira conjunta, agregada e anonimizada, e se voltam para propósitos estritamente acadêmicos.

Todos os gráficos apresentados neste trabalho têm como fonte as duas matrizes referidas - ANEXOS 1 e 2 - e foram elaborados, pelo autor, especificamente para a construção desta pesquisa. 
2. Do universo de teses e dissertações ao perfil de egressos

Como mencionei acima, esta pesquisa se baseia no levantamento proposto por Fernando Dias Menezes de Almeida, inclusive em seu recorte, um estudo de caso na área de Direito Administrativo. Mas há, aqui, uma diferença a ser considerada na construção desse recorte. O interesse de Fernando Dias Menezes de Almeida recaía, naquela obra, sobre uma "visão de conjunto", a partir da qual seria possível observar "exemplos significativos de pesquisa", padrões de "enfoque administrativista", para assim identificar uma "teoria do Direito Administrativo". ${ }^{14}$

Em razão dessa escolha metodológica, o autor inclui em seu levantamento teses e dissertações que, mesmo escritas em outras áreas do programa de pós-graduação, como Direito Econômico e Direito Processual, contém importantes indícios do tratamento teórico do Direito Administrativo no Brasil. Pela mesma razão, o autor também inclui teses docentes em sua matriz (teses de livre-docência e de titularidade).

$\mathrm{O}$ interesse deste artigo, nessa nuance, é diferente. Aqui, o objetivo é estudar uma área - em sentido formal - do programa de pós-graduação em Direito, como caso exemplar de seu perfil de egressos. Em razão disso, foram excluídas as teses e dissertações defendidas em áreas correlatas, bem como as teses docentes. Privilegiou-se, assim, um recorte estritamente formal, já que o interesse recai sobre o programa, e sobre a área de Direito Administrativo com um estudo de caso possivelmente generalizável no horizonte desse programa. ${ }^{15}$

A pesquisa também se restringiu ao intervalo dos últimos trinta e dois anos, simbolicamente demarcados pelo advento da atual Constituição da República, em 5 de outubro de 1988. Como o foco está no perfil recente de egressos, o intervalo foi divido em quatro períodos de oito anos: 1989-1996, 1997-2004, 2005-2012, e 2013-2020. Os três primeiros períodos estão cobertos pela primeira matriz (ANEXO 1). O quarto período (e mais recente) está coberto pela segunda matriz (ANEXO 2). Todos os dados constantes da presente pesquisa encontram-se organizados em torno desses quatro períodos.

A tabela a seguir traz quantidades absolutas de teses e dissertações defendidas na área de Direito Administrativo ao longo dos quatro períodos analisados:

14 ALMEIDA, Fernando Dias Menezes de. Formação da teoria do direito administrativo no Brasil. São Paulo: Quartier Latin, 2015, p. 282, 284 e 390.

15 Nesse mesmo sentido, não foram considerados como egressos os discentes vinculados a outros programas de pós-graduação (da USP ou externos à USP), eventualmente coorientados por docentes da área. Foram, contudo, consideradas as coorientações envolvendo docentes da área de direito administrativo e outros docentes de outras áreas do mesmo programa (pós-graduação em direito, FDUSP). 
Tabela 1

Teses e dissertações na área de Direito Administrativo (quantitativo, pós-88)

\begin{tabular}{c|c|c|c|c} 
& 89 a 96 & 97 a 04 & 05 a 12 & 13 a 20 \\
\hline Mestrado & 5 & 21 & 45 & 65 \\
\hline Doutorado & 5 & 9 & 23 & 37 \\
\hline Total & 10 & 30 & 68 & 102 \\
\hline
\end{tabular}

O crescimento da área, ainda que não seja abrupto, é extremamente significativo, como evidencia o gráfico a seguir:

\section{Gráfico}

\section{Evolução - área de direito administrativo - pós-88}

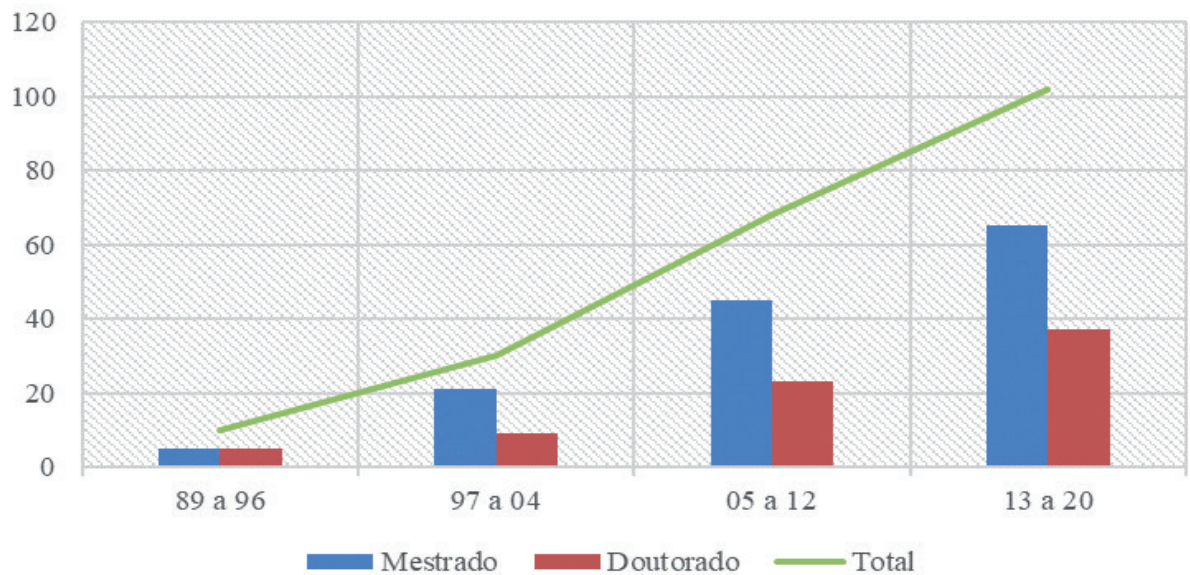

Mas, aqui, é preciso fazer o trânsito do universo de teses e dissertações para o perfil de egressos. Devido à sequência entre mestrado e doutorado, comum na tradição universitária brasileira, não são todas as dissertações de mestrado que indicam "egressos" do programa. Dito de maneira simples, uma área só registra "egressos de mestrado", em sentido próprio, quando seu autor opta por não defender uma tese de doutorado na mesma área. No mesmo sentido, contar todas as teses e dissertações como "egressos" produziria o equívoco de contar duas vezes o mesmo pesquisador - uma vez por seu mestrado, outra por seu doutorado - o que produziria importantes distorções na elaboração dos perfis.

Assim, para essa pesquisa, adotou-se o seguinte procedimento: (i) foram calculados, antes do levantamento estatístico, quais pesquisadores apareciam em duplicidade nas matrizes, por terem desenvolvido, na área de Direito Administrativo, 
tanto uma dissertação de mestrado quanto uma tese de doutorado; (ii) pesquisadores que se enquadravam nessa hipótese - grifados em azul nos ANEXOS 1 e 2 - foram contados como egressos ao tempo da conclusão de suas teses de doutorado, último título da formação no âmbito da pós-graduação brasileira;(iii) considerou-se como universo de todas as informações aqui apresentadas o número de egressos em cada um dos períodos analisados, e não o número de teses e dissertações; (iv) apurou-se o percentual que, em cada período, corresponde ao número de doutorados precedidos por mestrados e mestrados seguidos de doutorados; (v) para o último período (2013-2020), considerou-se que todas as dissertações de mestrado produziram egressos, na medida em que eventuais doutorados consecutivos se encontram ainda em andamento.

Uma simples comparação ilustra o problema. No primeiro período analisado (1989-1996), há 10 teses e dissertações, contra 08 egressos (porque dois pesquisadores buscaram o doutorado na sequência da obtenção do título de mestre). No segundo período (1997-2004), há 30 teses e dissertações contra 20 egressos. No terceiro período (2005-2012), há 68 teses e dissertações contra 48 egressos. No quarto período (2013-2020), há 102 teses e dissertações contra 95 egressos. É preciso, portanto, ter atenção ao denominador do cálculo. Todos os dados apresentados neste trabalho, abaixo, tomam como universo o número de egressos, e não a quantidade de teses e dissertações.

Comparando os períodos entre si, no primeiro, $70 \%$ das teses e dissertações são ou doutorados escritos na sequência de um mestrado na mesma área (Direito Administrativo), ou mestrados escritos preliminarmente a teses de doutorado na mesma área. Os outros 30\% se constituem, nesse caso, de doutorados escritos sem prévia dissertação de mestrado ("doutorados diretos"), mestrados que não foram seguidos de doutorados (títulos de mestre como formação final em pós-graduação), ou ainda de situações de exogenia relativa da área (doutorados escritos por mestres em outras áreas, ou mestrados que foram sucedidos por doutorados em outras áreas). No segundo período (1997-2004), esse percentual cai de 70\% para 66,7\%. No terceiro período (2005-2012), cai de $66,7 \%$ para 58,8\%. Para o quarto período (2013-2020), o cálculo não se aplica, na medida em que ainda não é possível avaliar com alguma precisão quantos mestrados serão seguidos de doutorado na mesma área, na medida em que eventuais doutorados consecutivos se encontrem ainda em andamento. É de se notar, no entanto, uma tendência de queda nesse "percentual de continuidade" entre mestrado e doutorado, o que pode indicar tanto o aumento da exogenia da área de Direito Administrativo quanto a relativa autonomização funcional entre os dois títulos.

Feita, portanto, a ressalva sobre o denominador dos dados percentuais aqui apresentados - insista-se, o quantitativo de egressos - é possível avançar na análise. Ainda na discussão da relação entre mestrado e doutorado, observa-se o percentual de egressos por título: 


\section{Gráfico 2}

\section{Percentual de egressos, por titulação (1989-2020)}

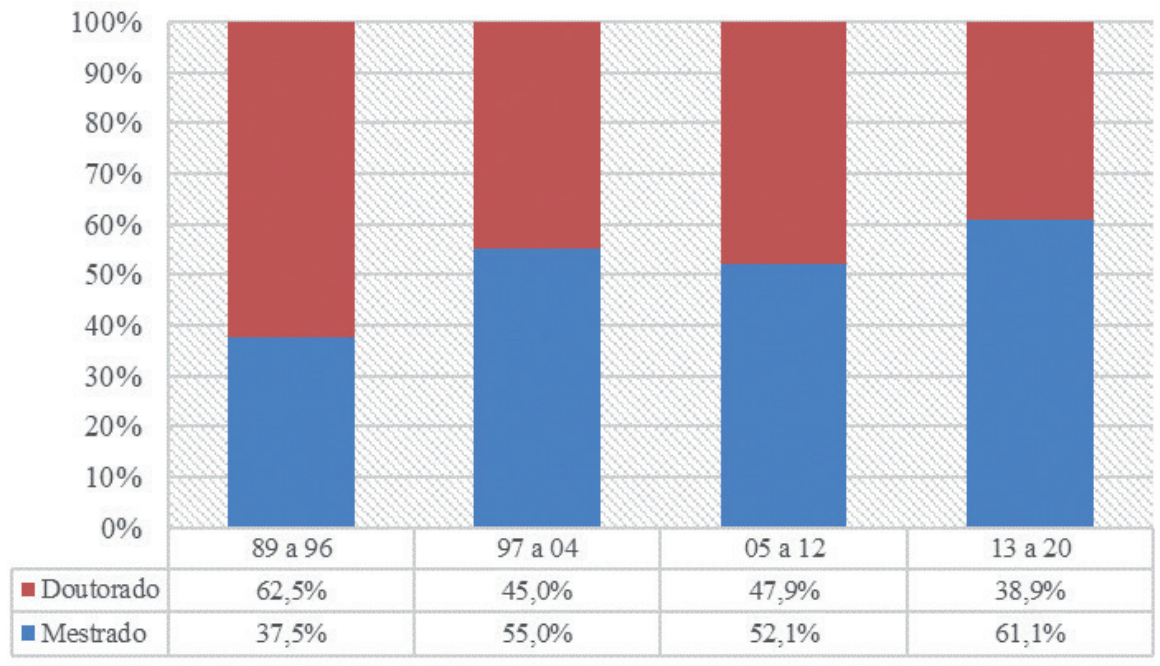

O gráfico ilustra tendência de aumento do percentual de egressos do programa com o título de mestre, o que é esperável diante da progressiva evolução do número de dissertações de mestrado (Gráfico 1). Mas ele também sugere, se tomado em conjunto com os demais dados aqui apresentados, que o título de mestre, para parte significativa dos discentes do programa, é suficiente diante de suas aspirações profissionais e pessoais.

\section{Perfil dos egressos: visão geral}

Tendo atravessado brevemente a discussão sobre mestrado e doutorado, a pesquisa chega ao seu objetivo imediato: o perfil dos egressos. Nesta seção, propõese uma visão geral, de todo, para na seção subsequente (seção 4), detalhar o perfil profissional dos egressos, por título, ao longo dos quatro períodos analisados.

Os egressos foram agrupados no universo das seguintes profissões jurídicas: (i) advogados, consultores jurídicos, autônomos, sócios de escritório de advocacia, administradores de empresas e membros de bancas de advogados, excetuandose os advogados e defensores públicos (a categoria foi abreviada como "Adv. Pr."); (ii) advogados públicos e procuradores, excetuando-se os procuradores de justiça (“Proc.”); (iii) promotores, procuradores de justiça, e demais órgãos do Ministério Público (“Prom.”); (iv) juízes, desembargadores e demais magistrados judiciais (“Mag.”); (v) assistentes comissionados em tribunais, judiciais ou administrativos (“Assis.”); (vi) 
agentes em funções de governo e de burocracia administrativa, excetuando-se posições judiciais e advocatícias (“Gov.”); (vii) pesquisadores dedicados à docência e à pesquisa em tempo integral (“Pesq.”); e (viii) defensores públicos concursados (“Def. Pub.”)

No caso de egressos com mais de um enquadramento possível, considerouse o mais duradouro, especialmente no caso dos aposentados. Subsidiariamente, nas hipóteses em que não foi possível avaliar a duração do vínculo, considerou-se a atividade profissional mais recente. ${ }^{16}$

Uma visão global dos egressos, somando os trinta e dois anos analisados e sem qualquer distinção de título, produz a seguinte distribuição:

\section{Gráfico 3}

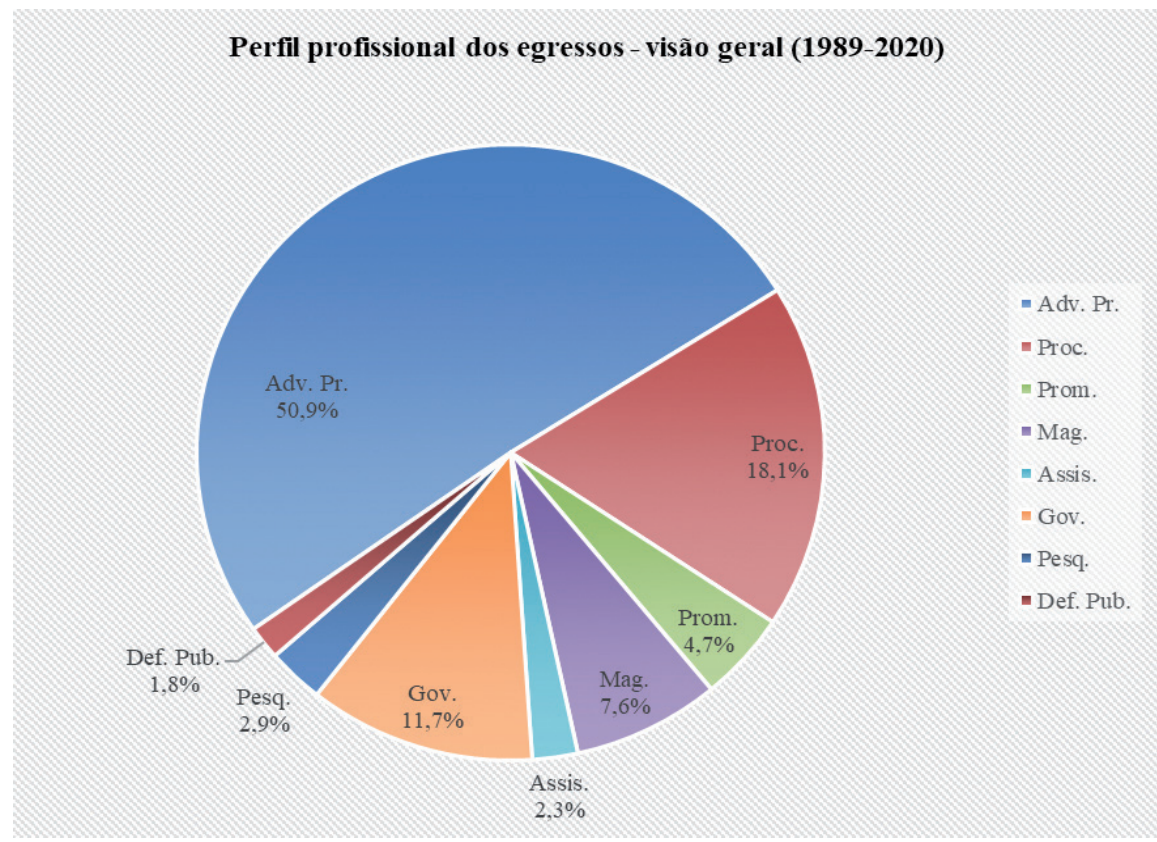

Considerando os períodos em que a pesquisa se divide, bem como a diferença de título (mestrado e doutorado), o número de egressos se distribui por profissão jurídica da seguinte maneira:

16 No caso de procuradores que também exercem, em concomitância, a advocacia privada, priorizou-se o vínculo público. 


\section{Gráfico 4 \\ Quantitativo de egressos por profissão jurídica}

89 a 96

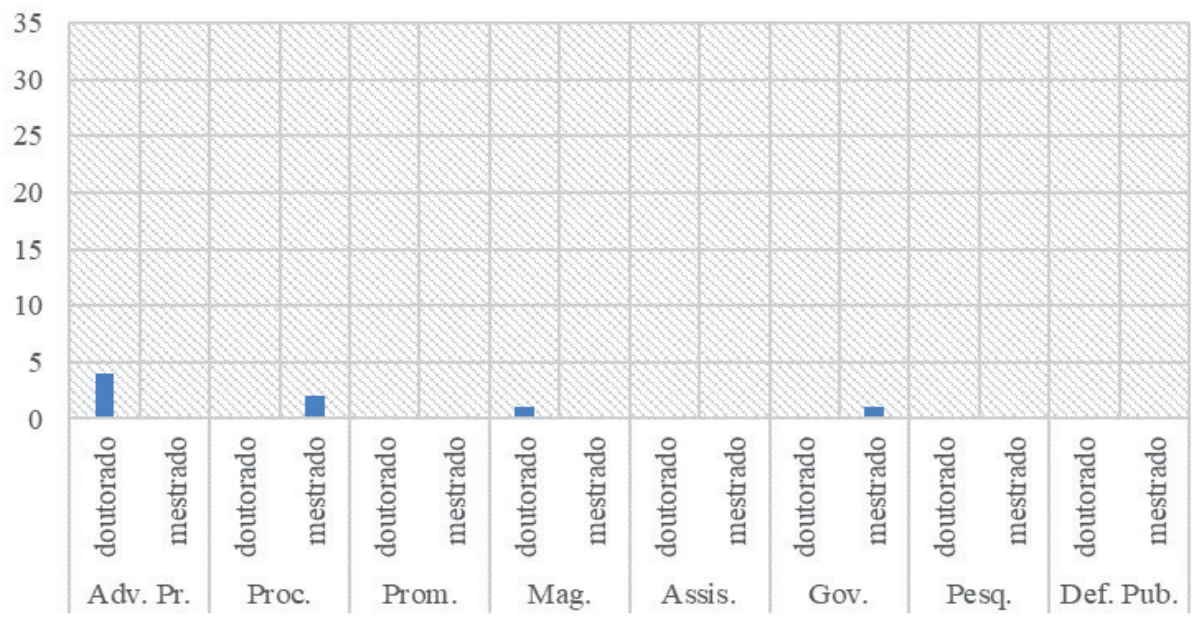

97 a 04

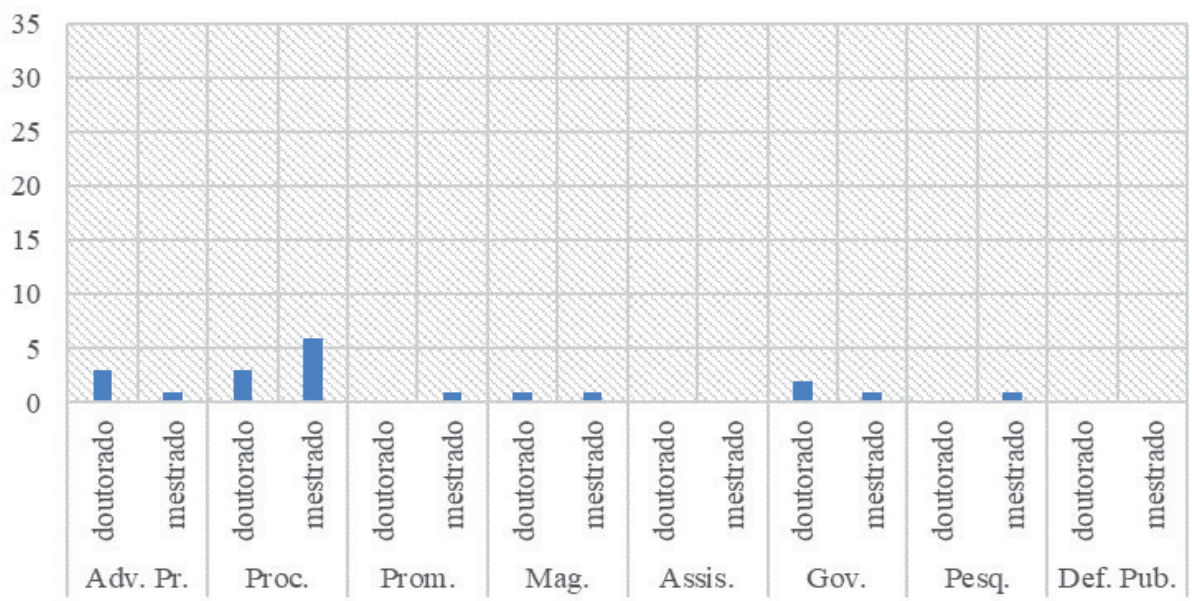


05 a 12

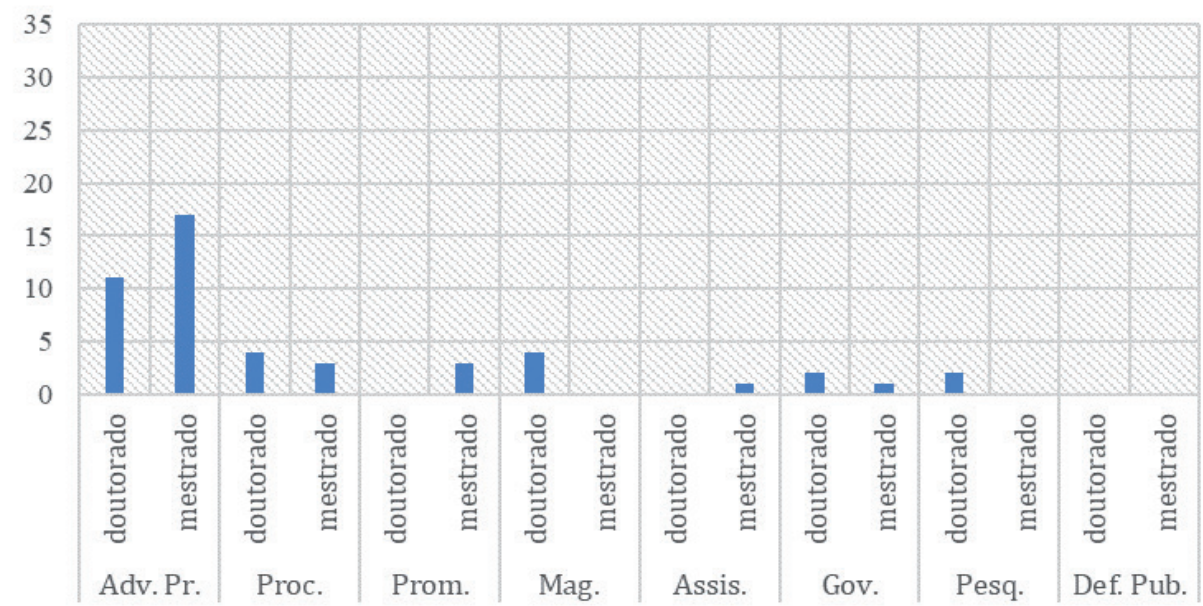

13 a 20

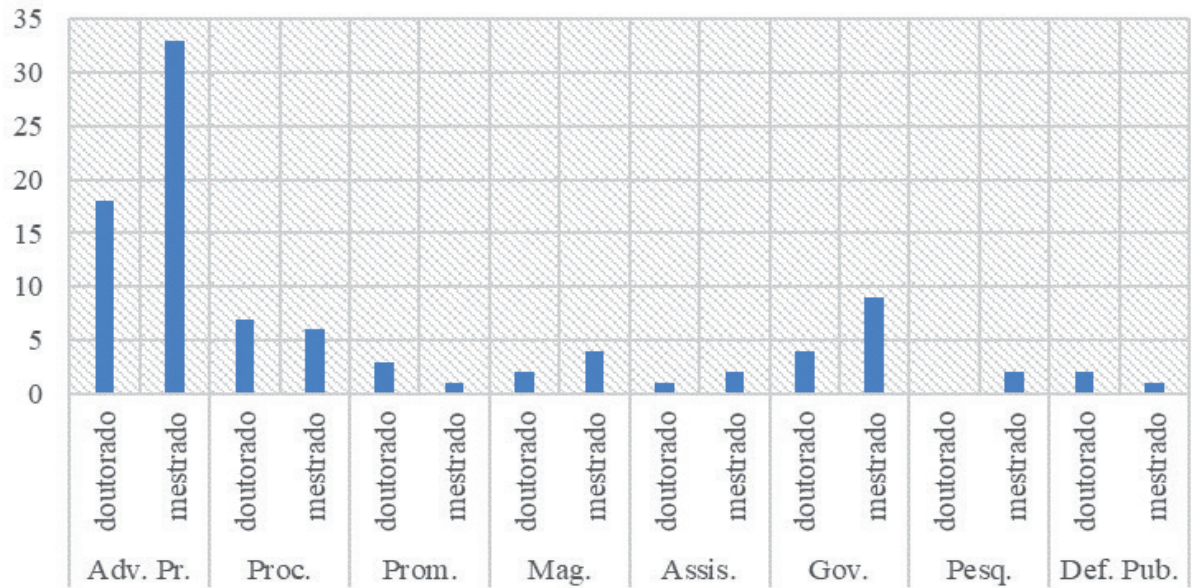

Dentre os diversos padrões que podem ser observados nos gráficos acima, destaca-se o predomínio da advocacia entre os egressos. Juntos, advogados e procuradores respondem por algo em torno de $70 \%$ dos egressos da área (Gráfico 3). No entanto, o predomínio de procuradores parece ter dado lugar, nos últimos dezesseis anos, à prevalência da advocacia privada (Gráfico 4). Chama atenção também o percentual baixo, mas relativamente estável, de egressos ocupados com a magistratura e com funções governamentais (Gráfico 4). 
Um ponto que também parece estar claro é o de que o crescimento da área de Direito Administrativo não é apenas quantitativo, mas também qualitativo. Se no primeiro período analisado os egressos se dividem basicamente entre profissões jurídicas mais "tradicionais" - advocacia e magistratura - no quarto há egressos em todas as profissões jurídicas examinadas.

Do ponto de vista evolutivo, parece também confirmada a transição de um perfil mais próximo da administração pública, do "múnus público", para um perfil mais próximo do mercado (setor de serviços). Se forem agrupadas todas as profissões organicamente públicas - procuradoria, promotoria, magistratura, assistência, governo e defensoria - e contrastadas com a advocacia privada e com a pesquisa profissional, produz-se o seguinte cenário:

\section{Gráfico 5}

\section{Perfil de egressos na área de direito administrativo: público vs. privado (1989-2020)}

Adv. Priv. $\quad$ Ag. Publ. $\quad$ Pesq. T. Int.

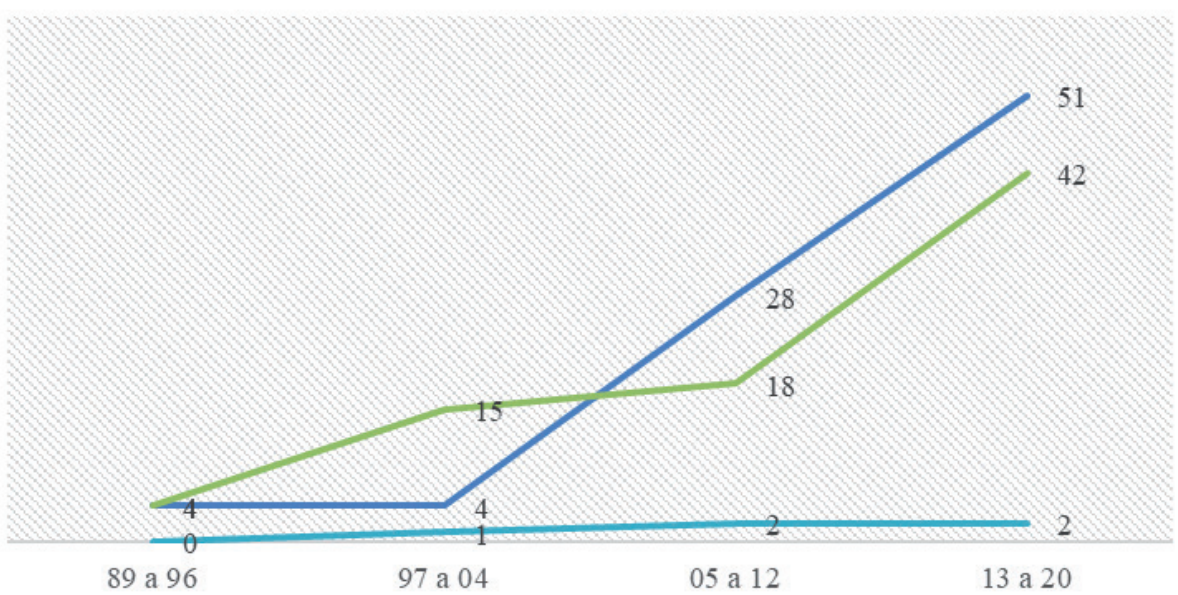

As curvas do gráfico permitem, inclusive, mapear o momento em que a transição ocorre, por volta da primeira década de 2000, quando a curva da advocacia privada (“Adv. Priv.”) toca a curva das profissões organicamente públicas (“Ag. Pub.”). 
Particularidade da área, a transição parece ser uma expressão do que, no plano teórico, vem sendo descrito como uma passagem, metodológica, de um Direito Administrativo "ex parte principe" para um Direito Administrativo "ex parte populi". ${ }^{17}$

O gráfico também aponta para o surgimento, ainda que tímido, de egressos em dedicação integral à docência e à pesquisa ("Pesq. T. Int.").

4. Perfil dos egressos: visão detalhada

O detalhamento dos dados apresentados no tópico anterior procura correlacionar o maior número possível de variáveis em torno do perfil profissional dos egressos. Assim, investiga-se a ocupação dos egressos por período e por título, conforme o gráfico abaixo.

\section{Gráfico 6}

\section{Perfil de egressos por período e por título}

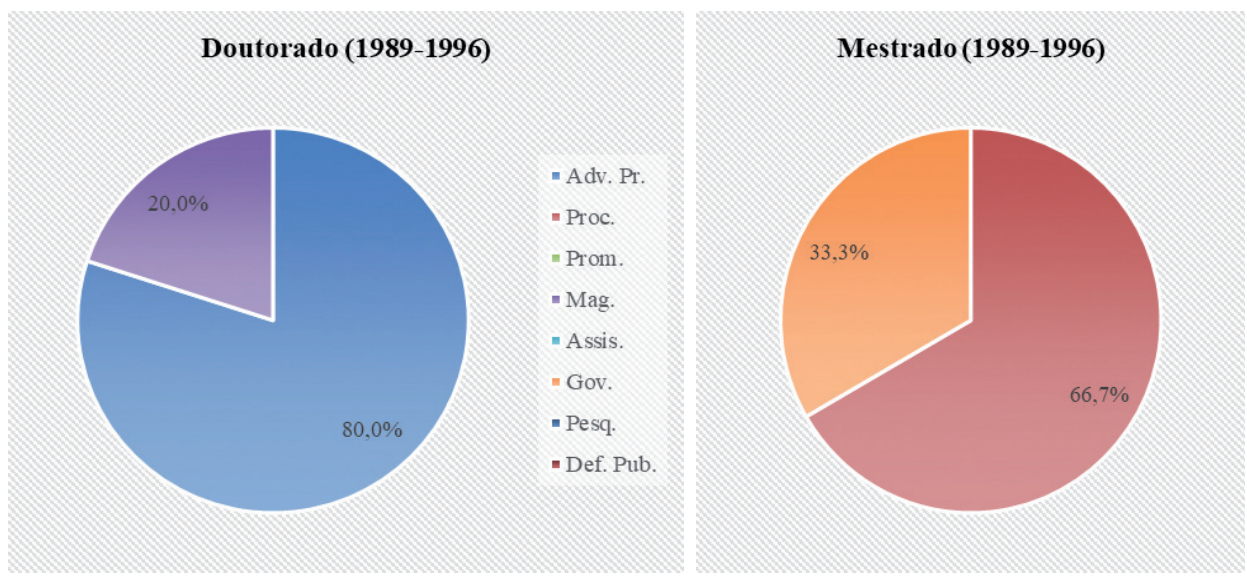

Para esse diagnóstico, v. MARQUES NETO, Floriano de Azevedo. A bipolaridade do direito administrativo e sua superação. SUNDFELD, Carlos Ari; JURKSAITIS, Guilherme Jardim (org.). Contratos públicos e direito administrativo. São Paulo: Malheiros, 2015, especialmente p. 367-382 
Doutorado (1997-2004)

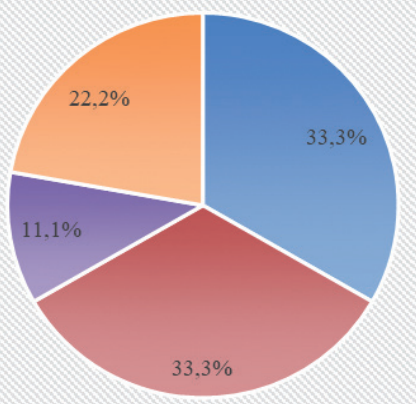

Doutorado (2005-2012)

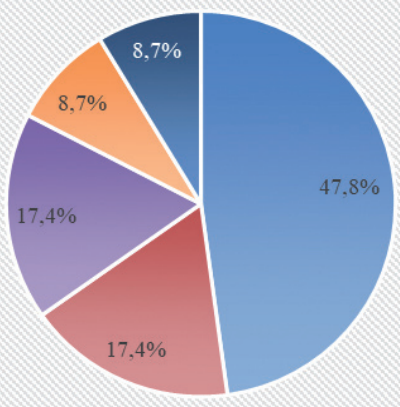

Doutorado (2013-2020)

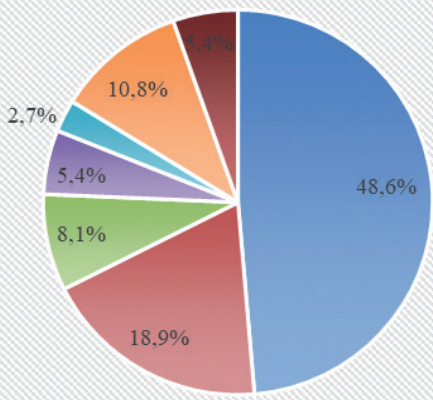

= Adv. Pr.

- Proc.

= Prom.

- Mag.

- Assis.

- Gov.

- Pesq.

- Def. Pub.

- Adv. Pr.

- Proc.

= Prom.

- Mag.

- Assis.

- Gov.

- Pesq.

- Def. Pub.

- Adv. Pr.

- Proc.

- Prom.

- Mag.

- Assis.

- Gov.

- Pesq.

- Def. Pub.
Mestrado (1997-2004)

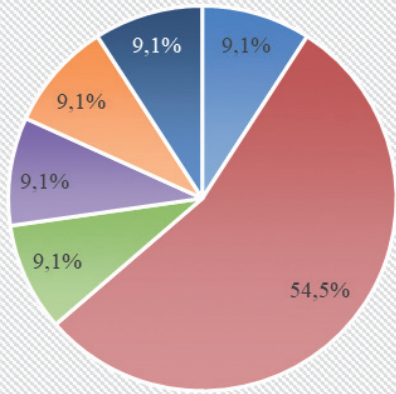

Mestrado (2005-2012)

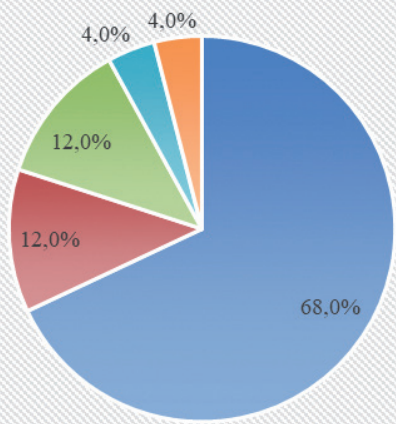

Mestrado (2013-2020)

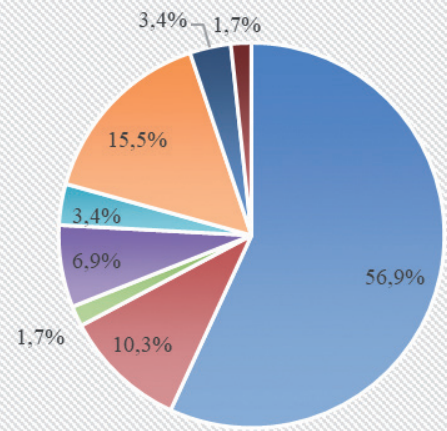

Os cálculos que proporcionaram a apuração de todos os percentuais acima se encontram detalhados no ANEXO 3. 
Longe de buscar uma análise exauriente de todas as informações trazidas acima, o que evidentemente fugiria ao escopo deste artigo, o propósito desta seção é o de simplesmente mapear em detalhes a evolução dos perfis de egressos nos períodos analisados.

Assim, é possível explorar, por exemplo, a correlação entre as profissões jurídicas, os títulos e os períodos de tempo. Por exemplo, é possível levantar hipóteses como a de que egressos no mestrado (ou seja, os egressos que não buscam em sequência o título de doutor) são majoritariamente advogados. Ou, no mesmo sentido, a hipótese de que os egressos em funções judiciais buscam, de maneira geral, o título de doutor. Ou ainda, a hipótese mais geral de que o mestrado é comparativamente mais propício a refletir tendências profissionais e oscilações de ocasião (antes em relação à procuradoria, depois em relação à advocacia) do que o doutorado, cuja distribuição de egressos se mantém mais constante nos quatro períodos observados.

Nada disso é conclusivo, mas é justamente aí onde está a importância desse tipo de investigação. A confirmação de hipóteses como essas depende de pesquisa empírica ulterior, mas que pressupõe, de toda maneira, uma etapa preliminar na qual dados da realidade social possam se traduzir em informações capazes de sustentar um projeto de pesquisa.

Busca-se, em síntese, consolidar um repositório de dados sobre quem desenvolve a ciência jurídica no Brasil. O que se traz nesta seção é, portanto, de interesse não apenas das instâncias de gestão do ensino superior no Brasil, como também da sociologia brasileira que volta ao estudo das profissões jurídicas contemporâneas.

\section{Perfil dos egressos: docência}

A última parte da pesquisa realizada se volta à docência. É bastante conhecida a intuição geral de que os programas de pós-graduação - e especialmente um programa tão tradicional quanto o da Faculdade de Direito da USP - são vocacionados a formar docentes. Mas, no presente universo de pesquisa - a área de Direito Administrativo - de que maneira isso tem acontecido? Quantos docentes o programa formou? Egressos do mestrado ou do doutorado? Esses docentes trabalham em que tipo de instituição? Lecionam para quem? Em que nível de formação?

Para direcionar essas respostas, a pesquisa do percentual de docentes levou em consideração não só o número absoluto de egressos docentes (Tabela 2 e Gráfico 7 , a seguir), mas também o título a eles conferido pelo programa (mestrado ou doutorado), e o tipo de instituição de ensino em que lecionam. Nesse último aspecto, as instituições analisadas foram agrupadas em três grandes grupos: (i) instituições de ensino superior públicas; (ii) instituições de ensino superior privadas; e (iii) instituições que oferecem 
cursos de pós-graduação lato sensu, especialização, mestrados profissionalizantes e demais modalidades de atualização direcionadas ao mercado.

Considerando-se os quatro períodos analisados, bem como a diferença entre mestrado (M) e doutorado (D), tem-se o seguinte quantitativo:

Tabela 2

Quantitativo de egressos docentes, por título e modalidade de docência (1989-2020)

\begin{tabular}{l|c|c|c|c|c|c|c|c} 
& \multicolumn{2}{|c|}{89 a 96} & \multicolumn{2}{c|}{97 a 04} & \multicolumn{2}{c|}{05 a 12} & \multicolumn{2}{c}{13 a 20} \\
\cline { 2 - 11 } & $\mathrm{D}$ & $\mathrm{M}$ & $\mathrm{D}$ & $\mathrm{M}$ & $\mathrm{D}$ & $\mathrm{M}$ & $\mathrm{D}$ & $\mathrm{M}$ \\
\hline Universidades Públicas & 1 & 0 & 3 & 0 & 7 & 1 & 1 & 0 \\
\hline Universidades Privadas & 2 & 0 & 2 & 2 & 2 & 1 & 8 & 1 \\
\hline PG lato, Esp., Cursos Prof. & 2 & 0 & 0 & 0 & 4 & 1 & 7 & 0 \\
\hline
\end{tabular}

\section{Gráfico 7}

\section{Quantitativo de egressos docentes e evolução do programa}

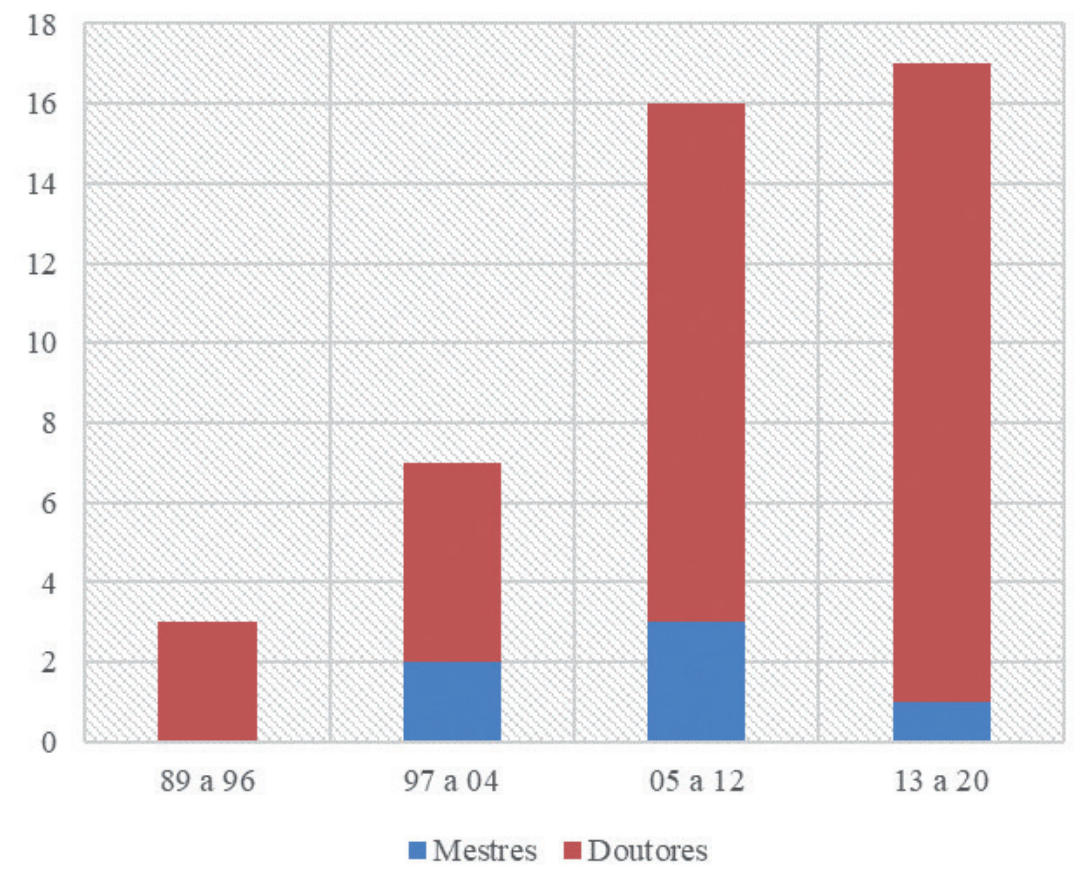




\section{Gráfico 8}

Egressos docentes: modalidade de docência

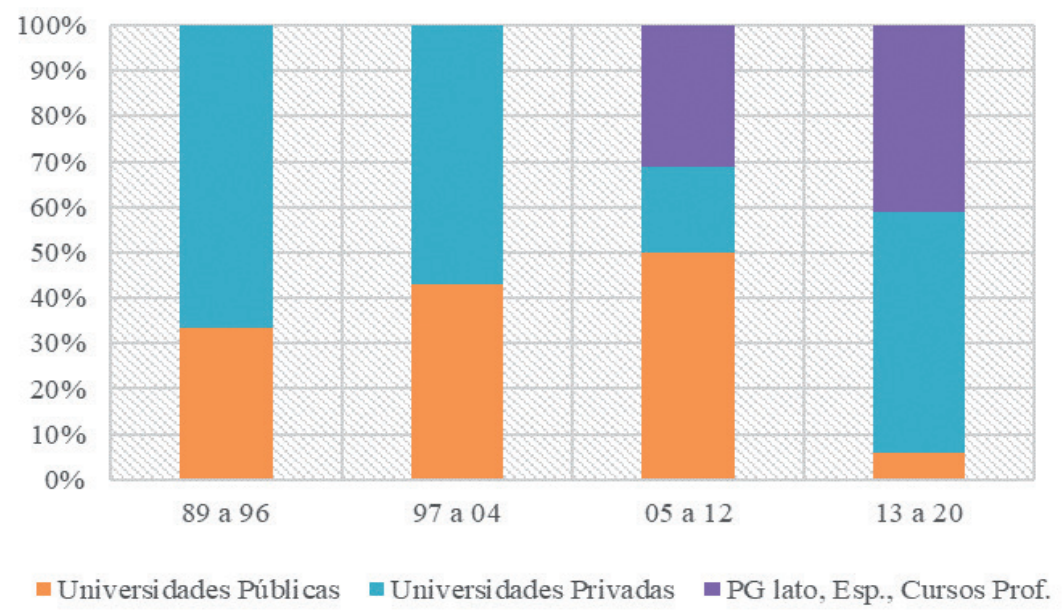

\section{Gráfico 9}

\section{Percentual de egressos docentes (pós-88)}

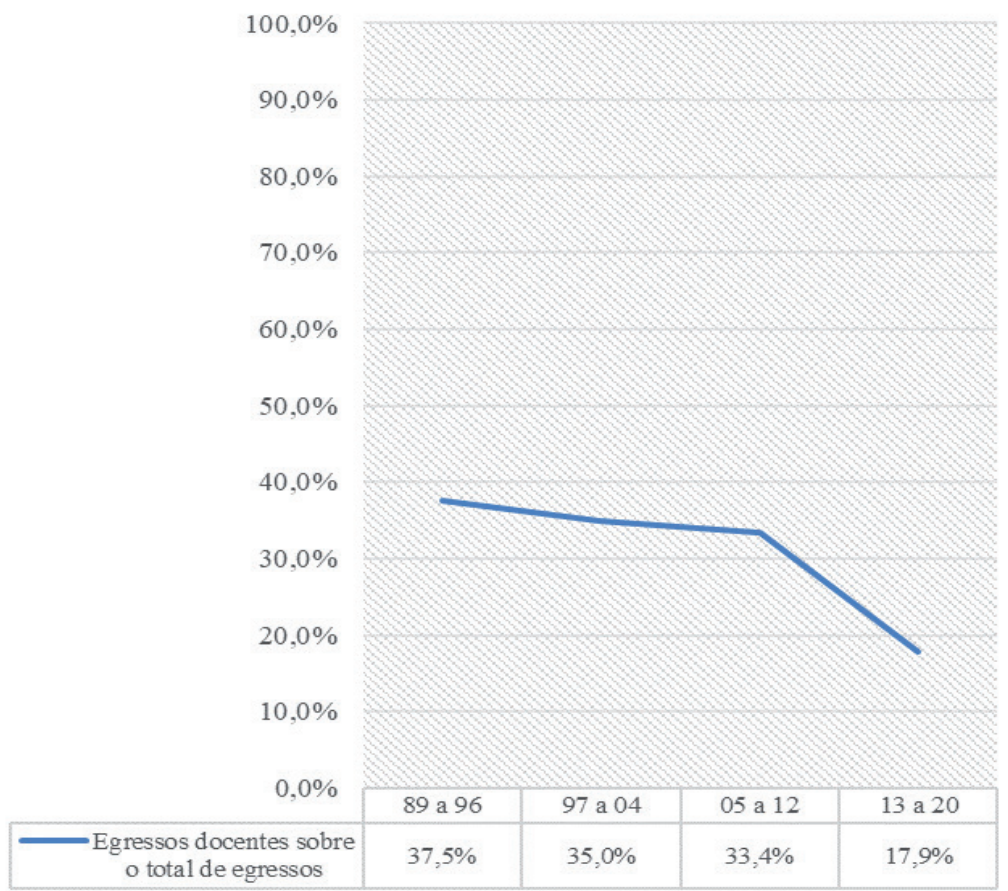


Os dados sobre egressos docentes devem ser interpretados com cuidado. Há, de fato, um aumento na quantidade absoluta de docentes formados pelo programa de pós-graduação na área de Direito Administrativo (Gráfico 7). Porém, essa informação precisa ser lida em cotejo com o crescimento expressivo do programa no período analisado (Gráfico 1). O que se observa, em termos percentuais, é a queda no percentual de egressos que se ocupa da docência, acentuadamente no período mais recente (20132020). Como aponta o Gráfico 9, o percentual de docentes, que vinha estabilizado próximo a um terço do total de egressos desde a década de 1980, não tem conseguido acompanhar a mesma velocidade de crescimento do programa, caindo para menos de $18 \%$ no último período observado.

Dessa maneira, do ponto de vista estatístico, o programa, ao menos no estudo de caso analisado, tem formado menos professores. Essa tendência pode estar ligada tanto a mudanças no perfil dos discentes que buscam o programa, quanto a problemas de ordem conjuntural, como a retração dos investimentos públicos em ensino superior a partir de 2016, a superveniência da "PEC da bengala" em 2015, e as políticas de esvaziamento praticadas nas universidades públicas, especialmente federais, a partir de 2019.

Isso não significa, naturalmente, que haja menos "intenções de docência" entre os discentes do programa. $\mathrm{O}$ dado indica, apenas, que os egressos do programa têm encontrado, em termos proporcionais, menores "oportunidades de docência". ${ }^{18}$ Nesse sentido, a observação das intenções discentes, bem como de sua eventual "frustração" diante de condições conjunturais menos favoráveis, é passível de verificação empírica, e pode constituir pergunta de pesquisa no interesse de trabalhos futuros, lançados sobre as bases do presente levantamento. Por ora, basta assinalar que há uma notável diminuição do que se poderia denominar como "vocação de formação docente" do programa, o que parece estar associado a um fenômeno recente e complexo, ainda não completamente conhecido, ligado a uma combinação de fatores envolvendo, em alguma proporção, mudanças no perfil discente e alterações da conjuntura social.

Em favor de uma perspectiva mais conjuntural dessa tendência, o Gráfico 8 assinala a retração da docência em universidades públicas no último período. Parece estar em curso, por razões que também merecem investigação empírica aprofundada, uma verdadeira "migração" dos egressos docentes para as instituições de ensino superior privadas.

Outra variável relevante, nessa distribuição, é a introdução e o crescimento de uma "terceira" modalidade de docência, voltada à especialização e à atualização profissional. Isso coincide com a explosão, nas últimas duas décadas, dos

18 Devo esta ponderação a Fernando Dias Menezes de Almeida, que gentilmente a apresentou diante da leitura de uma versão preliminar deste capítulo. 
cursos de "mestrado profissionalizante", "especialização jurídica" e "pós-graduação lato sensu", oferecidos sobretudo por instituições privadas, por vezes em colaboração com associações de advogados. Sendo, aliás, o "advogado" o perfil dominante na área examinada (Gráficos 4, 5 e 6), é mesmo de se esperar que essa modalidade de docência atraia especial atenção dos egressos. Em síntese, a retração da docência nas universidades públicas parece vir acompanhada da expansão de iniciativas de ensino superior imbuídas de viés precipuamente mercadológico.

Por fim, é preciso notar a tradição de prevalência, na área examinada, de doutores entre os egressos docentes (Gráfico 7). De um lado, isso reforça a conexão histórica do programa com a docência em universidades públicas, para as quais, no pós88 , o título de doutor é condição de ingresso. Por outro lado, parece assinalar que mesmo as instituições privadas têm, paulatinamente, exigido o doutorado de seus docentes.

De qualquer maneira, essa tendência parece apontar que a "vocação de formação docente" do programa é muito mais ligada ao doutorado do que ao mestrado. Com efeito, o que se observa, ao menos na área de Direito Administrativo, é uma forte "inclinação ao doutorado" por parte dos discentes com ambições docentes, o que pode sugerir um elemento não trivial - a formação docente - como critério-chave de diferenciação funcional entre o mestrado e o doutorado.

\section{Conclusão}

A pesquisa aqui apresentada é mais importante por aquilo que ela deixa em aberto do que por aquilo que ela efetivamente responde. Mapear profissionalmente os egressos de um programa tão grande e tão diversificado como o da Faculdade de Direito da Universidade de São Paulo, entretanto, não poderia ter qualquer pretensão que não fosse a de levantar dados capazes de informar hipóteses. Quais são essas hipóteses, e qual sua validade empírica, são questões que compõem uma agenda de pesquisa que estudos como este têm a pretensão de fomentar e, no limite, induzir.

Não há hipótese, por mais abstrata que seja, que não parta de um problema razoavelmente diagnosticado. E, como foi dito, é esse o propósito de um levantamento que dá a conhecer algo que é, simultaneamente, tão presente e tão ausente na realidade de um programa de pós-graduação. Tão presente porque egressos são, ainda na condição de discentes, a razão de ser de qualquer experiência de ensino e pesquisa em pós-graduação. Vivem o programa, e é a partir dessa vivência que o programa se identifica e se constitui. Tão ausente porque, como se referiu na seção 1 deste artigo, dados sobre egressos são escassos, difusos, difíceis de obter e de sistematizar. Mas é preciso trazer visibilidade para o perfil de egressos, sob pena de não se conseguir diagnosticar quem se tem formado na pós-graduação em Direito no Brasil. 
Esse diagnóstico é, portanto, a etapa prévia de toda e qualquer hipótese sobre a formação jurídica de nível superior. Sem clareza sobre o perfil do que se forma, é impossível compreender as bases da formação jurídica nacional, ou endereçar qualquer proposta de mudança nas condições presentes. E isso, como mencionado na seção 4 deste artigo, é algo que interessa tanto ao sociólogo do ensino jurídico quanto ao gestor, público ou privado, que esteja em condição de problematizar a formação jurídica em pós-graduação. Só é possível avançar na questão sobre quem se quer formar na pósgraduação quando há clareza sobre quem se tem formado na pós-graduação.

Dessa clareza de diagnóstico depende tanto a sociologia do ensino jurídico - tópico tradicionalmente prestigiado na sociologia jurídica brasileira - quanto a gestão universitária do ensino jurídico - que no momento atravessa, no plano regulatório nacional, crise política sem qualquer precedente. Dessa clareza depende, em uma síntese mais estrutural, porém não menos crítica, a própria ciência jurídica em formação. 


\section{ANEXO 1}

- $1989-1996$

\begin{tabular}{|l|l|c|c|l|}
\hline STERMAN, Sonia & $\begin{array}{l}\text { Responsabilidade do Estado } \\
\text { pelos danos causados por } \\
\text { movimentos multitudinários }\end{array}$ & 1989 & $\begin{array}{l}\text { Dissertação } \\
\text { de mestrado }\end{array}$ & $\begin{array}{l}\text { José Cretella } \\
\text { Júnior }\end{array}$ \\
\hline $\begin{array}{l}\text { OLIVEIRA, Heli } \\
\text { Alves de }\end{array}$ & Do licenciamento ambiental & 1989 & $\begin{array}{l}\text { Dissertação } \\
\text { de mestrado }\end{array}$ & $\begin{array}{l}\text { José Cretella } \\
\text { Júnior }\end{array}$ \\
\hline UYEDA, Massami & $\begin{array}{l}\text { Da competência em matéria } \\
\text { administrativa }\end{array}$ & 1992 & $\begin{array}{c}\text { Tese de } \\
\text { doutorado }\end{array}$ & $\begin{array}{l}\text { José Cretella } \\
\text { Júnior }\end{array}$ \\
\hline $\begin{array}{l}\text { CINTRA, Fernando } \\
\text { Pimentel }\end{array}$ & $\begin{array}{l}\text { O princípio da subsidiariedade } \\
\text { no direito administrativo }\end{array}$ & 1993 & $\begin{array}{l}\text { Dissertação } \\
\text { de mestrado }\end{array}$ & $\begin{array}{l}\text { Maria Sylvia } \\
\text { Pietro Di }\end{array}$ \\
\hline $\begin{array}{l}\text { CASTRO, Carlos } \\
\text { Borges de }\end{array}$ & $\begin{array}{l}\text { O desvio de finalidade nas } \\
\text { licitações }\end{array}$ & 1993 & $\begin{array}{c}\text { Tese de } \\
\text { doutorado }\end{array}$ & $\begin{array}{l}\text { José Cretella } \\
\text { Júnior }\end{array}$ \\
\hline PEREIRA, Marcelo & $\begin{array}{l}\text { O serviço público na } \\
\text { atualidade }\end{array}$ & 1993 & $\begin{array}{c}\text { Tese de } \\
\text { doutorado }\end{array}$ & Odete Medauar \\
\hline $\begin{array}{l}\text { CASTILHO, } \\
\text { Jocélia de Almeida }\end{array}$ & $\begin{array}{l}\text { A 'exceptio non adimpleti } \\
\text { contractus' no âmbito do } \\
\text { direito administrativo }\end{array}$ & 1994 & $\begin{array}{l}\text { Dissertão } \\
\text { de mestrado }\end{array}$ & $\begin{array}{l}\text { José Cretella } \\
\text { Júnior }\end{array}$ \\
\hline $\begin{array}{l}\text { GOMES, Antonieta } \\
\text { Rosa }\end{array}$ & $\begin{array}{l}\text { Da mutabilidade dos } \\
\text { contratos administrativos }\end{array}$ & 1994 & $\begin{array}{l}\text { Dissertação } \\
\text { de mestrado }\end{array}$ & $\begin{array}{l}\text { Maria Sylvia } \\
\text { Zanella Di } \\
\text { Pietro }\end{array}$ \\
\hline $\begin{array}{l}\text { AMARAL FILHO, } \\
\text { Marcos Jordão } \\
\text { Teixeira do }\end{array}$ & $\begin{array}{l}\text { Privatização no Estado } \\
\text { contemporâneo }\end{array}$ & $\begin{array}{l}\text { Ongese de } \\
\text { doutorado } \\
\text { direito administrativo } \\
\text { Alves de }\end{array}$ & $\begin{array}{l}\text { Odete Medauar } \\
\text { doutorado }\end{array}$ & Odete Medauar \\
\hline
\end{tabular}


- $1997-2004$

\begin{tabular}{|c|c|c|c|c|}
\hline $\begin{array}{l}\text { LOPES, Vera Maria de } \\
\text { Oliveira Nusdeo }\end{array}$ & $\begin{array}{l}\text { Concessões de serviço público } \\
\text { de rádio e televisão }\end{array}$ & 1997 & $\begin{array}{l}\text { Dissertação } \\
\text { de mestrado }\end{array}$ & $\begin{array}{l}\text { Maria Sylvia } \\
\text { Zanella Di } \\
\text { Pietro }\end{array}$ \\
\hline $\begin{array}{l}\text { PEREZ, Marcos } \\
\text { Augusto }\end{array}$ & $\begin{array}{l}\text { Institutos de } \begin{array}{l}\text { participação } \\
\text { popular na } \\
\text { pública }\end{array} \\
\end{array}$ & 1999 & $\begin{array}{l}\text { Dissertação } \\
\text { de mestrado }\end{array}$ & $\begin{array}{l}\text { Maria Sylvia } \\
\text { Zanella Di } \\
\text { Pietro }\end{array}$ \\
\hline $\begin{array}{l}\text { PORFÍRIO } \\
\text { JÚNIOR, Nelson de } \\
\text { Freitas }\end{array}$ & $\begin{array}{l}\text { Responsabilidade do Estado } \\
\text { em face do dano ambiental }\end{array}$ & 1999 & $\begin{array}{l}\text { Dissertação } \\
\text { de mestrado }\end{array}$ & Odete Medauar \\
\hline $\begin{array}{l}\text { TOBA, Marcos } \\
\text { Maurício }\end{array}$ & $\begin{array}{l}\text { Contornos modernos da teoria } \\
\text { do processo administrativo }\end{array}$ & 1999 & $\begin{array}{l}\text { Dissertação } \\
\text { de mestrado }\end{array}$ & Odete Medauar \\
\hline $\begin{array}{l}\text { CINTRA, Fernando } \\
\text { Pimentel }\end{array}$ & $\begin{array}{l}\text { O princípio da subsidiariedade } \\
\mathrm{e} \text { as formas de parceria } \\
\text { aplicáveis ao ensino público } \\
\text { de nível básico }\end{array}$ & 1999 & $\begin{array}{c}\text { Tese de } \\
\text { doutorado }\end{array}$ & $\begin{array}{l}\text { Maria Sylvia } \\
\text { Zanella Di } \\
\text { Pietro }\end{array}$ \\
\hline $\begin{array}{l}\text { SANTOS, Márcia } \\
\text { Walquiria Batista dos }\end{array}$ & Licença urbanística & 1999 & $\begin{array}{c}\text { Tese de } \\
\text { doutorado }\end{array}$ & Odete Medauar \\
\hline $\begin{array}{l}\text { RAMOS, Dora } \\
\text { Maria de Oliveira }\end{array}$ & \begin{tabular}{|lll} 
Aspectos & jurídicos & da \\
terceirização no âmbito da & no ámica \\
administração pública & \\
\end{tabular} & 2000 & $\begin{array}{l}\text { Dissertação } \\
\text { de mestrado }\end{array}$ & $\begin{array}{l}\text { Maria Sylvia } \\
\text { Zanella Di } \\
\text { Pietro } \\
\end{array}$ \\
\hline $\begin{array}{l}\text { MARTINS } \\
\text { JÚNIOR, Wallace } \\
\text { Paiva }\end{array}$ & Probidade administrativa & 2000 & $\begin{array}{l}\text { Dissertação } \\
\text { de mestrado }\end{array}$ & $\begin{array}{l}\text { Maria Sylvia } \\
\text { Zanella Di } \\
\text { Pietro }\end{array}$ \\
\hline $\begin{array}{l}\text { BUCCI, Maria Paula } \\
\text { Dallari }\end{array}$ & $\begin{array}{l}\text { Direito administrativo e } \\
\text { políticas públicas }\end{array}$ & 2000 & $\begin{array}{l}\text { Tese de } \\
\text { doutorado }\end{array}$ & $\begin{array}{l}\text { Maria Sylvia } \\
\text { Zanella Di } \\
\text { Pietro }\end{array}$ \\
\hline $\begin{array}{l}\text { ZAGO, Lívia } \\
\text { Maria Armentano } \\
\text { Koenigstein }\end{array}$ & O princípio da impessoalidade & 2000 & $\begin{array}{c}\text { Tese de } \\
\text { doutorado }\end{array}$ & Odete Medauar \\
\hline $\begin{array}{l}\text { TANAKA, Sônia } \\
\text { Yuriko }\end{array}$ & $\begin{array}{l}\text { Concepção dos contratos } \\
\text { administrativos }\end{array}$ & 2001 & $\begin{array}{c}\text { Tese de } \\
\text { doutorado }\end{array}$ & Odete Medauar \\
\hline $\begin{array}{l}\text { ALMEIDA, Maria } \\
\text { Tereza Perez de }\end{array}$ & $\begin{array}{l}\text { O Estado e a responsabilidade } \\
\text { civil por omissão na proteção } \\
\text { aomeio ambiente }\end{array}$ & 2001 & $\begin{array}{l}\text { Dissertação } \\
\text { de mestrado }\end{array}$ & $\begin{array}{l}\text { Edmir Netto de } \\
\text { Araújo }\end{array}$ \\
\hline $\begin{array}{l}\text { OLIVEIRA, Ruth } \\
\text { Helena Pimentel de }\end{array}$ & $\begin{array}{l}\text { R e s p o n s a b i l i d a d e } \\
\text { extracontratual das entidades } \\
\text { prestadoras de serviços } \\
\text { públicos }\end{array}$ & 2001 & $\begin{array}{l}\text { Dissertação } \\
\text { de mestrado }\end{array}$ & $\begin{array}{l}\text { Edmir Netto de } \\
\text { Araújo }\end{array}$ \\
\hline LAMY, Marcelo & $\begin{array}{l}\text { A utilização da franquia pela } \\
\text { administração pública }\end{array}$ & 2001 & $\begin{array}{l}\text { Dissertação } \\
\text { de mestrado }\end{array}$ & $\begin{array}{l}\text { Edmir Netto de } \\
\text { Araújo }\end{array}$ \\
\hline $\begin{array}{l}\text { CARVALHO } \\
\text { NETO, Tarcísio } \\
\text { Vieira de }\end{array}$ & $\begin{array}{l}\text { Responsabilidade civil } \\
\text { extracontratual por omissão do } \\
\text { Estado }\end{array}$ & 2002 & $\begin{array}{l}\text { Dissertação } \\
\text { de mestrado }\end{array}$ & Odete Medauar \\
\hline
\end{tabular}




\begin{tabular}{|c|c|c|c|c|}
\hline $\begin{array}{l}\text { LOUREIRO } \\
\text { FILHO, Lair da Silva }\end{array}$ & $\begin{array}{l}\text { Responsabilidade pública } \\
\text { por atividade judiciária }\end{array}$ & 2002 & $\begin{array}{l}\text { Dissertação } \\
\text { de mestrado }\end{array}$ & Odete Medauar \\
\hline $\begin{array}{l}\text { NOHARA, Irene } \\
\text { Patrícia }\end{array}$ & $\begin{array}{l}\text { O motivo no ato } \\
\text { administrativo }\end{array}$ & 2002 & $\begin{array}{l}\text { Dissertação } \\
\text { de mestrado }\end{array}$ & $\begin{array}{l}\text { Maria Sylvia } \\
\text { Zanella Di } \\
\text { Pietro }\end{array}$ \\
\hline $\begin{array}{l}\text { SANTOS, Fábio } \\
\text { Ribeiro dos }\end{array}$ & $\begin{array}{l}\text { O exercício do poder de polícia } \\
\text { nodireito ambiental }\end{array}$ & 2002 & $\begin{array}{l}\text { Dissertação } \\
\text { de mestrado }\end{array}$ & Odete Medauar \\
\hline $\begin{array}{l}\text { SANTOS NETO, } \\
\text { João Antunes dos }\end{array}$ & $\begin{array}{l}\text { Da anulação 'ex officio' do } \\
\text { ato administrativo }\end{array}$ & 2002 & $\begin{array}{l}\text { Dissertação } \\
\text { de mestrado }\end{array}$ & $\begin{array}{l}\text { Maria Sylvia } \\
\text { Zanella Di } \\
\text { Pietro }\end{array}$ \\
\hline BASTOS, Aline Dias & $\begin{array}{lr}\text { Conceitos } & \text { jurídicos } \\
\text { i n d e t e r m i n a d o s : } \\
\text { discricionariedade } \\
\text { vinculação }\end{array}$ & 2002 & $\begin{array}{l}\text { Dissertação } \\
\text { de mestrado }\end{array}$ & $\begin{array}{l}\text { Edmir Netto de } \\
\text { Araújo }\end{array}$ \\
\hline $\begin{array}{l}\text { KIM, Richard Paulro } \\
\text { Pae }\end{array}$ & $\begin{array}{l}\text { Responsabilidade do Estado } \\
\text { nasocupações ilícitas }\end{array}$ & 2002 & $\begin{array}{l}\text { Tese de } \\
\text { doutorado }\end{array}$ & Odete Medauar \\
\hline $\begin{array}{l}\text { AMORIM, Anadil } \\
\text { Abujabra }\end{array}$ & $\begin{array}{l}\text { Sanções } \\
\text { ambientais }\end{array}$ & 2002 & $\begin{array}{l}\text { Dissertação } \\
\text { de mestrado }\end{array}$ & $\begin{array}{l}\text { Edmir Netto de } \\
\text { Araújo }\end{array}$ \\
\hline $\begin{array}{l}\text { TOBA, Marcos } \\
\text { Maurício }\end{array}$ & $\begin{array}{l}\text { Novos parâmetros de atuação } \\
\text { da administração pública }\end{array}$ & 2003 & $\begin{array}{l}\text { Tese de } \\
\text { doutorado }\end{array}$ & Odete Medauar \\
\hline $\begin{array}{l}\text { DI PIERRO } \\
\text { JÚNIOR, Miguel } \\
\text { Thomaz }\end{array}$ & A desapropriação urbanística & 2003 & $\begin{array}{l}\text { Dissertação } \\
\text { de mestrado }\end{array}$ & $\begin{array}{l}\text { Maria Sylvia } \\
\text { Zanella Di } \\
\text { Pietro }\end{array}$ \\
\hline $\begin{array}{l}\text { MARTINS } \\
\text { JÚNIOR, Wallace } \\
\text { Paiva }\end{array}$ & $\begin{array}{l}\text { O princípio da transparência } \\
\text { administrativa }\end{array}$ & 2003 & $\begin{array}{l}\text { Tese de } \\
\text { doutorado }\end{array}$ & $\begin{array}{l}\text { Maria Sylvia } \\
\text { Zanella Di } \\
\text { Pietro }\end{array}$ \\
\hline $\begin{array}{l}\text { LACERDA, Paulo } \\
\text { Francisco Bastos Von } \\
\text { Bruck }\end{array}$ & $\begin{array}{l}\text { Fundamentos do processo } \\
\text { administrativo disciplinar: } \\
\text { justiça administrativa }\end{array}$ & 2004 & $\begin{array}{l}\text { Dissertação } \\
\text { de mestrado }\end{array}$ & $\begin{array}{l}\text { Edmir Netto de } \\
\text { Araújo }\end{array}$ \\
\hline $\begin{array}{l}\text { RAMOS, Dora } \\
\text { Maria de Oliveira }\end{array}$ & $\begin{array}{l}\text { O poder sancionatório da } \\
\text { administração pública }\end{array}$ & 2004 & $\begin{array}{l}\text { Tese de } \\
\text { doutorado }\end{array}$ & $\begin{array}{l}\text { Maria Sylvia } \\
\text { Zanella Di } \\
\text { Pietro }\end{array}$ \\
\hline $\begin{array}{l}\text { PINTO, Luciana } \\
\text { Ferreira Leite }\end{array}$ & $\begin{array}{l}\text { O 'contrato de gestão': } \\
\text { instrumentos para a reforma } \\
\text { da administração pública }\end{array}$ & 2004 & $\begin{array}{l}\text { Dissertação } \\
\text { de mestrado }\end{array}$ & $\begin{array}{l}\text { Maria Sylvia } \\
\text { Zanella Di } \\
\text { Pietro }\end{array}$ \\
\hline $\begin{array}{l}\text { RACHED, Danielle } \\
\text { Hanna }\end{array}$ & $\begin{array}{l}\text { O devido processo legal } \\
\text { da Agência Nacional de } \\
\text { Telecomunicações (Anatel) }\end{array}$ & 2004 & $\begin{array}{l}\text { Dissertação } \\
\text { de mestrado }\end{array}$ & $\begin{array}{l}\text { Edmir Netto de } \\
\text { Araújo }\end{array}$ \\
\hline $\begin{array}{l}\text { HORBACH, } \\
\text { Carlos Bastide }\end{array}$ & $\begin{array}{l}\text { Teoria das nulidades do ato } \\
\text { administrativo }\end{array}$ & 2004 & $\begin{array}{l}\text { Tese de } \\
\text { doutorado }\end{array}$ & Odete Medauar \\
\hline
\end{tabular}


- $2005-2012$

\begin{tabular}{|c|c|c|c|c|}
\hline $\begin{array}{l}\text { CASAGRANDE } \\
\text { FILHO, Ary }\end{array}$ & $\begin{array}{l}\text { Os julgamentos } \\
\text { administrativos das agências } \\
\text { reguladoras em face do art. } \\
5^{\circ}, \text { XXXV, da Constituição da } \\
\text { República }\end{array}$ & 2005 & $\begin{array}{l}\text { Dissertação } \\
\text { de mestrado }\end{array}$ & $\begin{array}{l}\text { Floriano de } \\
\text { Azevedo } \\
\text { Marques Neto }\end{array}$ \\
\hline $\begin{array}{l}\text { TUCUNDUVA } \\
\text { SOBRINHO, Ruy } \\
\text { Cardozo de Mello }\end{array}$ & $\begin{array}{l}\text { Atos administrativos editados } \\
\text { pelo poder judiciário }\end{array}$ & 2005 & $\begin{array}{l}\text { Dissertação } \\
\text { de mestrado }\end{array}$ & $\begin{array}{l}\text { Edmir Netto de } \\
\text { Araújo }\end{array}$ \\
\hline $\begin{array}{l}\text { ROCHA, Regina } \\
\text { Bernardes }\end{array}$ & $\begin{array}{l}\text { Dispensa e inexigibilidade: } \\
\text { exceções legais à } \\
\text { obrigatoriedade de prévio } \\
\text { procedimento licitatório nas } \\
\text { contratações efetuadas pela } \\
\text { administração pública }\end{array}$ & 2005 & $\begin{array}{l}\text { Dissertação } \\
\text { de mestrado }\end{array}$ & $\begin{array}{l}\text { Edmir Netto de } \\
\text { Araújo }\end{array}$ \\
\hline $\begin{array}{l}\text { MAGALHÃES } \\
\text { JÚNIOR, Antônio } \\
\text { Sílvio }\end{array}$ & $\begin{array}{l}\text { O controle externo da } \\
\text { administração pública pelo } \\
\text { tribunal de contas }\end{array}$ & 2005 & $\begin{array}{c}\text { Tese de } \\
\text { doutorado }\end{array}$ & $\begin{array}{l}\text { Edmir Netto de } \\
\text { Araújo }\end{array}$ \\
\hline $\begin{array}{l}\text { SHECAIRA, Cibele } \\
\text { Cristina Baldassa } \\
\text { Muniz }\end{array}$ & $\begin{array}{l}\text { Agências reguladoras: princípio } \\
\text { da eficiência e controle } \\
\text { judicial }\end{array}$ & 2005 & $\begin{array}{l}\text { Dissertação } \\
\text { de mestrado }\end{array}$ & $\begin{array}{l}\text { Edmir Netto de } \\
\text { Araújo }\end{array}$ \\
\hline $\begin{array}{l}\text { PORFÍRIO } \\
\text { JÚNIOR, Nelson de } \\
\text { Freitas }\end{array}$ & Acordos ambientais & 2005 & $\begin{array}{c}\text { Tese de } \\
\text { doutorado }\end{array}$ & Odete Medauar \\
\hline $\begin{array}{l}\text { ARAGÃO, } \\
\text { Alexandre Santos de }\end{array}$ & $\begin{array}{l}\text { A dimensão e o papel dos } \\
\text { serviços públicos no Estado } \\
\text { democrático }\end{array}$ & 2005 & $\begin{array}{c}\text { Tese de } \\
\text { doutorado }\end{array}$ & Odete Medauar \\
\hline MARRARA, Thiago & $\begin{array}{l}\text { A teoria do domínio público } \\
\text { urbano e as infra-estruturas de } \\
\text { serviços públicos }\end{array}$ & 2005 & $\begin{array}{l}\text { Dissertação } \\
\text { de mestrado }\end{array}$ & $\begin{array}{l}\text { Maria Sylvia } \\
\text { Zanella Di } \\
\text { Pietro }\end{array}$ \\
\hline $\begin{array}{l}\text { OLIVEIRA, } \\
\text { Gustavo Henrique } \\
\text { Justino }\end{array}$ & $\begin{array}{|lr|}\text { O contrato de gestão na } \\
\begin{array}{l}\text { administração } \\
\text { brasileira }\end{array} & \text { pública } \\
\end{array}$ & 2005 & $\begin{array}{c}\text { Tese de } \\
\text { doutorado }\end{array}$ & Odete Medauar \\
\hline $\begin{array}{l}\text { PEREZ, Marcos } \\
\text { Augusto }\end{array}$ & \begin{tabular}{|lrrr} 
O risco & no & contrato de \\
concessão & de & serviços \\
públicos & & &
\end{tabular} & 2005 & $\begin{array}{c}\text { Tese de } \\
\text { doutorado }\end{array}$ & Odete Medauar \\
\hline $\begin{array}{l}\text { BARRETO, Dora } \\
\text { Maria Vendramini }\end{array}$ & $\begin{array}{l}\text { A prova no processo } \\
\text { administrativo disciplinar }\end{array}$ & 2006 & $\begin{array}{l}\text { Dissertação } \\
\text { de mestrado }\end{array}$ & $\begin{array}{l}\text { Edmir Netto de } \\
\text { Araújo }\end{array}$ \\
\hline $\begin{array}{l}\text { NOIA, Fernanda da } \\
\text { Cruz }\end{array}$ & $\begin{array}{l}\text { Efeitos do tombamento sobre } \\
\text { a propriedade privada }\end{array}$ & 2006 & $\begin{array}{l}\text { Dissertação } \\
\text { de mestrado }\end{array}$ & $\begin{array}{l}\text { Fernando Dias } \\
\text { Menezes de } \\
\text { Almeida }\end{array}$ \\
\hline
\end{tabular}




\begin{tabular}{|c|c|c|c|c|}
\hline $\begin{array}{l}\text { OLIVEIRA, Raul } \\
\text { Miguel Freitas de }\end{array}$ & $\begin{array}{l}\text { Regime próprio dos servidores } \\
\text { públicos: princípios do } \\
\text { equilíbrio financeiro e } \\
\text { atuarial, da contribuição e da } \\
\text { solidariedade }\end{array}$ & 2006 & $\begin{array}{l}\text { Dissertação } \\
\text { de mestrado }\end{array}$ & $\begin{array}{l}\text { Maria Sylvia } \\
\text { Zanella Di } \\
\text { Pietro }\end{array}$ \\
\hline $\begin{array}{l}\text { SANTOS, Fábio } \\
\text { Ribeiro dos }\end{array}$ & $\begin{array}{l}\text { O poder normativo do } \\
\text { Conselho Nacional do Meio } \\
\text { Ambiente - Conama }\end{array}$ & 2006 & $\begin{array}{c}\text { Tese de } \\
\text { doutorado }\end{array}$ & Odete Medauar \\
\hline $\begin{array}{l}\text { SANTOS NETO, } \\
\text { João Antunes dos }\end{array}$ & $\begin{array}{l}\text { O impacto dos direitos } \\
\text { humanos fundamentais no } \\
\text { direito administrativo }\end{array}$ & 2006 & $\begin{array}{c}\text { Tese de } \\
\text { doutorado }\end{array}$ & $\begin{array}{l}\text { Maria Sylvia } \\
\text { Zanella Di } \\
\text { Pietro }\end{array}$ \\
\hline $\begin{array}{l}\text { SALGADO FILHO, } \\
\text { Nilo Spínola }\end{array}$ & $\begin{array}{l}\text { Contrato administrativo: } \\
\text { efeitos da invalidação }\end{array}$ & 2006 & $\begin{array}{l}\text { Dissertação } \\
\text { de mestrado }\end{array}$ & $\begin{array}{l}\text { Edmir Netto de } \\
\text { Araújo }\end{array}$ \\
\hline $\begin{array}{l}\text { NOHARA, Irene } \\
\text { Patrícia }\end{array}$ & $\begin{array}{l}\text { Limites à razoabilidade nos } \\
\text { atos administrativos }\end{array}$ & 2006 & $\begin{array}{c}\text { Tese de } \\
\text { doutorado }\end{array}$ & $\begin{array}{l}\text { Maria Sylvia } \\
\text { Zanella Di } \\
\text { Pietro }\end{array}$ \\
\hline $\begin{array}{l}\text { BAPTISTA, Patrícia } \\
\text { Ferreira }\end{array}$ & $\begin{array}{l}\text { Segurança jurídica e proteção } \\
\text { da confiança legítima no direito } \\
\text { brasileiro análise sistemática e } \\
\text { critérios de aplicação no direito } \\
\text { administrativo brasileiro }\end{array}$ & 2006 & $\begin{array}{c}\text { Tese de } \\
\text { doutorado }\end{array}$ & Odete Medauar \\
\hline $\begin{array}{l}\text { CARVALHAES } \\
\text { NETO, Eduardo } \\
\text { Hayden }\end{array}$ & $\begin{array}{l}\text { Regulação da } \\
\text { universalização de serviços } \\
\text { públicos concedidos: o } \\
\text { caso brasileiro dos serviços de } \\
\text { telecomunicações }\end{array}$ & 2007 & $\begin{array}{l}\text { Dissertação } \\
\text { de mestrado }\end{array}$ & $\begin{array}{l}\text { Edmir Netto de } \\
\text { Araújo }\end{array}$ \\
\hline $\begin{array}{l}\text { GUIMARÃES, } \\
\text { Bernardo Strobel }\end{array}$ & $\begin{array}{l}\text { Da regulação como função de } \\
\text { direito administrativo }\end{array}$ & 2007 & $\begin{array}{l}\text { Dissertação } \\
\text { de mestrado }\end{array}$ & $\begin{array}{l}\text { Maria Sylvia } \\
\text { Zanella Di } \\
\text { Pietro }\end{array}$ \\
\hline $\begin{array}{l}\text { SCORSIM, Ericsom } \\
\text { Meister }\end{array}$ & $\begin{array}{l}\text { Estatuto dos serviços de } \\
\text { televisão por radiodifusão }\end{array}$ & 2007 & $\begin{array}{c}\text { Tese de } \\
\text { doutorado }\end{array}$ & Odete Medauar \\
\hline $\begin{array}{l}\text { FALDINI, Cristiana } \\
\text { Correa Conde }\end{array}$ & $\begin{array}{l}\text { Responsabilidade do Estado } \\
\text { pela prática de atos lícitos }\end{array}$ & 2007 & $\begin{array}{l}\text { Dissertação } \\
\text { de mestrado }\end{array}$ & $\begin{array}{l}\text { Fernando Dias } \\
\text { Menezes de } \\
\text { Almeida }\end{array}$ \\
\hline $\begin{array}{l}\text { FRANCO, João } \\
\text { Honório de Souza }\end{array}$ & $\begin{array}{l}\text { R e s p o n s a b i } 1 \text { i d a d e } \\
\text { extracontratual do Estado e } \\
\text { improbidade administrativa }\end{array}$ & 2007 & $\begin{array}{l}\text { Dissertação } \\
\text { de mestrado }\end{array}$ & $\begin{array}{l}\text { Edmir Netto de } \\
\text { Araújo }\end{array}$ \\
\hline $\begin{array}{l}\text { ADAMI, Mateus } \\
\text { Piva }\end{array}$ & $\begin{array}{l}\text { A discricionariedade } \\
\text { administrativa em face do } \\
\text { princípio da eficiência }\end{array}$ & 2007 & $\begin{array}{l}\text { Dissertação } \\
\text { de mestrado }\end{array}$ & $\begin{array}{l}\text { Floriano de } \\
\text { Azevedo } \\
\text { Marques Neto }\end{array}$ \\
\hline $\begin{array}{l}\text { MOTTA, Fabrício } \\
\text { Macedo }\end{array}$ & $\begin{array}{lll}\text { A função normativa } & \text { da } \\
\text { administração pública no } & \text { no } \\
\text { Brasil } & & \end{array}$ & 2007 & $\begin{array}{l}\text { Tese de } \\
\text { doutorado }\end{array}$ & Odete Medauar \\
\hline
\end{tabular}




\begin{tabular}{|c|c|c|c|c|}
\hline $\begin{array}{l}\text { PACHECO, } \\
\text { Clarissa Dertonio de } \\
\text { Sousa }\end{array}$ & $\begin{array}{l}\text { O controle jurisdicional do } \\
\text { silêncio administrativo }\end{array}$ & 2008 & $\begin{array}{l}\text { Dissertação } \\
\text { de mestrado }\end{array}$ & $\begin{array}{l}\text { Edmir Netto de } \\
\text { Araújo }\end{array}$ \\
\hline $\begin{array}{l}\text { VERZOLA, Maysa } \\
\text { Abrahão Tavares }\end{array}$ & $\begin{array}{l}\text { A sanção no direito } \\
\text { administrativo brasileiro }\end{array}$ & 2008 & $\begin{array}{l}\text { Dissertação } \\
\text { de mestrado }\end{array}$ & $\begin{array}{l}\text { Edmir Netto de } \\
\text { Araújo }\end{array}$ \\
\hline $\begin{array}{l}\text { RIBEIRO, Luís } \\
\text { Paulo Aliende }\end{array}$ & $\begin{array}{l}\text { A regulação da função pública } \\
\text { notarial e de registro }\end{array}$ & 2008 & $\begin{array}{c}\text { Tese de } \\
\text { doutorado }\end{array}$ & $\begin{array}{l}\text { Maria Sylvia } \\
\text { Zanella Di } \\
\text { Pietro }\end{array}$ \\
\hline $\begin{array}{l}\text { CUNHA, Cláudia } \\
\text { Polto }\end{array}$ & $\begin{array}{l}\text { Contrato de gestão no contexto } \\
\text { da evolução da administração } \\
\text { pública }\end{array}$ & 2008 & $\begin{array}{l}\text { Dissertação } \\
\text { de mestrado }\end{array}$ & $\begin{array}{l}\text { Fernando Dias } \\
\text { Menezes de } \\
\text { Almeida }\end{array}$ \\
\hline $\begin{array}{l}\text { GOMES, Wilton } \\
\text { Luís da Silva }\end{array}$ & $\begin{array}{l}\text { Inovações no regime jurídico } \\
\text { das desapropriações }\end{array}$ & 2009 & $\begin{array}{l}\text { Dissertação } \\
\text { de mestrado }\end{array}$ & $\begin{array}{l}\text { Maria Sylvia } \\
\text { Zanella Di } \\
\text { Pietro }\end{array}$ \\
\hline $\begin{array}{l}\text { MIGUEL, Luiz } \\
\text { Felipe Hadlich }\end{array}$ & $\begin{array}{l}\text { As garantias dadas ao } \\
\text { particular nas parcerias } \\
\text { público- privadas }\end{array}$ & 2009 & $\begin{array}{l}\text { Dissertação } \\
\text { de mestrado }\end{array}$ & Odete Medauar \\
\hline $\begin{array}{l}\text { GREGÓRIO, Rita } \\
\text { de Cássia Zuffo }\end{array}$ & $\begin{array}{l}\text { A responsabilidade civil do } \\
\text { Estado-juiz }\end{array}$ & 2009 & $\begin{array}{l}\text { Dissertação } \\
\text { de mestrado }\end{array}$ & $\begin{array}{l}\text { Edmir Netto de } \\
\text { Araújo }\end{array}$ \\
\hline $\begin{array}{l}\text { MARQUES, Fábio } \\
\text { Ferraz }\end{array}$ & $\begin{array}{l}\text { A prestação privada de } \\
\text { serviços públicos no Brasil }\end{array}$ & 2009 & $\begin{array}{l}\text { Dissertação } \\
\text { de mestrado }\end{array}$ & $\begin{array}{l}\text { Edmir Netto de } \\
\text { Araújo }\end{array}$ \\
\hline $\begin{array}{l}\text { SCHOENMAKER, } \\
\text { Janaína }\end{array}$ & $\begin{array}{l}\text { Controle das parcerias entre } \\
\text { o Estado e o terceiro setor } \\
\text { pelos tribunais de contas }\end{array}$ & 2009 & $\begin{array}{l}\text { Dissertação } \\
\text { de mestrado }\end{array}$ & Odete Medauar \\
\hline $\begin{array}{l}\text { NEGRINI, Ricardo } \\
\text { Augusto }\end{array}$ & $\begin{array}{l}\text { Os consórcios públicos no } \\
\text { direito brasileiro }\end{array}$ & 2009 & $\begin{array}{l}\text { Dissertação } \\
\text { de mestrado }\end{array}$ & $\begin{array}{l}\text { Maria Sylvia } \\
\text { Zanella Di } \\
\text { Pietro }\end{array}$ \\
\hline $\begin{array}{l}\text { MÂNICA, Fernando } \\
\text { Borges }\end{array}$ & \begin{tabular}{|lll} 
Participação & \multicolumn{2}{c}{ privada na } \\
prestação de & serviços \\
públicos de saúde & \\
\end{tabular} & 2009 & $\begin{array}{c}\text { Tese de } \\
\text { doutorado }\end{array}$ & Odete Medauar \\
\hline $\begin{array}{l}\text { MONTEIRO, Vera } \\
\text { Cristina Caspari }\end{array}$ & $\begin{array}{l}\text { A caracterização do contrato } \\
\text { de concessão após a edição da } \\
\text { Lei } 11.079 / 2004\end{array}$ & 2009 & $\begin{array}{c}\text { Tese de } \\
\text { doutorado }\end{array}$ & $\begin{array}{l}\text { Fernando Dias } \\
\text { Menezes de } \\
\text { Almeida } \\
\end{array}$ \\
\hline $\begin{array}{l}\text { TUCUNDUVA } \\
\text { SOBRINHO, Ruy } \\
\text { Cardozo de Mello }\end{array}$ & $\begin{array}{l}\text { Prescrição no processo } \\
\text { administrativo disciplinar }\end{array}$ & 2009 & $\begin{array}{l}\text { Tese de } \\
\text { doutorado }\end{array}$ & $\begin{array}{l}\text { Edmir Netto de } \\
\text { Araújo }\end{array}$ \\
\hline $\begin{array}{l}\text { MIRAGAYA, } \\
\text { Rodrigo Bracet }\end{array}$ & $\begin{array}{l}\text { A proteção da } \\
\text { legítima confiança } \\
\text { fundamental no princípio } \\
\text { administrativo atual }\end{array}$ & 2010 & $\begin{array}{l}\text { Dissertação } \\
\text { de mestrado }\end{array}$ & $\begin{array}{l}\text { Floriano de } \\
\text { Azevedo } \\
\text { Marques Neto }\end{array}$ \\
\hline
\end{tabular}




\begin{tabular}{|c|c|c|c|c|}
\hline $\begin{array}{l}\text { PALMA, Juliana } \\
\text { Bonacorsi de }\end{array}$ & \begin{tabular}{lr} 
Atuação & \multicolumn{2}{c}{ administrativa } \\
consensual: estudos dos \\
acordos substitutivos no \\
processo administrativo \\
sancionador
\end{tabular} & 2010 & $\begin{array}{l}\text { Dissertação } \\
\text { de mestrado }\end{array}$ & $\begin{array}{l}\text { Floriano de } \\
\text { Azevedo } \\
\text { Marques Neto }\end{array}$ \\
\hline $\begin{array}{l}\text { SCHWIND, Rafael } \\
\text { Walbach }\end{array}$ & $\begin{array}{l}\text { Remuneração do particular } \\
\text { nas concessões e parcerias } \\
\text { público-privadas }\end{array}$ & 2010 & $\begin{array}{l}\text { Dissertação } \\
\text { de mestrado }\end{array}$ & $\begin{array}{l}\text { Maria Sylvia } \\
\text { Zanella Di } \\
\text { Pietro }\end{array}$ \\
\hline $\begin{array}{l}\text { MIGUEL, Luiz } \\
\text { Felipe Hadlich }\end{array}$ & $\begin{array}{l}\text { As garantias dadas ao } \\
\text { particular nas parcerias } \\
\text { público-privadas }\end{array}$ & 2010 & $\begin{array}{c}\text { Dissertação } \\
\text { de mestrado }\end{array}$ & Odete Medauar \\
\hline $\begin{array}{l}\text { LIMA, Carolina } \\
\text { Caiado }\end{array}$ & $\begin{array}{l}\text { O convênio administrativo } \\
\text { colaborativo } \\
\text { transferência de recursos } \\
\text { públicos a entidades privadas } \\
\text { sem fins lucrativos como } \\
\text { instrumento dos mecanismos } \\
\text { diretos de fomento público }\end{array}$ & 2010 & $\begin{array}{l}\text { Dissertação } \\
\text { de mestrado }\end{array}$ & Odete Medauar \\
\hline $\begin{array}{l}\text { SOUZA, Leandro } \\
\text { Marins de }\end{array}$ & $\begin{array}{l}\text { Parcerias entre } \\
\text { administração pública e } \\
\text { terceiro setor: sistematização } \\
\text { e regulação }\end{array}$ & 2010 & $\begin{array}{c}\text { Tese de } \\
\text { doutorado }\end{array}$ & $\begin{array}{l}\text { Maria Sylvia } \\
\text { Zanella Di } \\
\text { Pietro }\end{array}$ \\
\hline $\begin{array}{l}\text { LUVIZOTTO, } \\
\text { Juliana Cristina }\end{array}$ & $\begin{array}{l}\text { Responsabilidade civil do } \\
\text { Estado legislador: atos } \\
\text { legislativos inconstitucionais e } \\
\text { constitucionais }\end{array}$ & 2010 & $\begin{array}{l}\text { Dissertação } \\
\text { de mestrado }\end{array}$ & $\begin{array}{l}\text { Edmir Netto de } \\
\text { Araújo }\end{array}$ \\
\hline $\begin{array}{l}\text { LINO, Fernanda } \\
\text { Noia da Costa }\end{array}$ & $\begin{array}{l}\text { A preservação do patrimônio } \\
\text { cultural urbano: fundamentos, } \\
\text { agentes e práticas } \\
\text { urbanísticas }\end{array}$ & 2010 & $\begin{array}{c}\text { Tese de } \\
\text { doutorado }\end{array}$ & $\begin{array}{l}\text { Fernando Dias } \\
\text { Menezes de } \\
\text { Almeida }\end{array}$ \\
\hline $\begin{array}{l}\text { BOCAFOLI, } \\
\text { Amarilis Inocente }\end{array}$ & $\begin{array}{l}\text { R e s p o n s a b i li d a d e } \\
\text { administrativa } \\
\text { funcionários públicos por } \\
\text { ineficiência }\end{array}$ & 2010 & $\begin{array}{l}\text { Dissertação } \\
\text { de mestrado }\end{array}$ & $\begin{array}{l}\text { Edmir Netto de } \\
\text { Araújo }\end{array}$ \\
\hline $\begin{array}{l}\text { OLIVEIRA, Raul } \\
\text { Miguel Freitas de }\end{array}$ & \begin{tabular}{llr} 
Concessão & \multicolumn{2}{c}{ florestal: } \\
exploração & sustentável & de \\
florestas & públicas & por \\
particular & &
\end{tabular} & 2010 & $\begin{array}{l}\text { Tese de } \\
\text { doutorado }\end{array}$ & $\begin{array}{l}\text { Maria Sylvia } \\
\text { Zanella Di } \\
\text { Pietro }\end{array}$ \\
\hline $\begin{array}{l}\text { RIBEIRO, Carlos } \\
\text { Vinícius Alves }\end{array}$ & $\begin{array}{l}\text { As funções extrajudiciais do } \\
\text { ministério público: natureza } \\
\text { jurídica, discricionariedade e } \\
\text { limites }\end{array}$ & 2011 & $\begin{array}{l}\text { Dissertação } \\
\text { de mestrado }\end{array}$ & $\begin{array}{l}\text { Maria Sylvia } \\
\text { Zanella Di } \\
\text { Pietro }\end{array}$ \\
\hline
\end{tabular}




\begin{tabular}{|c|c|c|c|c|}
\hline $\begin{array}{l}\text { SILVA, Maurício } \\
\text { Jayme e }\end{array}$ & $\begin{array}{l}\text { O regulamento autônomo } \\
\text { de licitações e contratações } \\
\text { das organizações sociais } \\
\text { no âmbito da Lei federal } n^{\circ} \\
9.637 / 98\end{array}$ & 2011 & $\begin{array}{l}\text { Dissertação } \\
\text { de mestrado }\end{array}$ & $\begin{array}{l}\text { Gustavo } \\
\text { Henrique } \\
\text { Justino de } \\
\text { Oliveira }\end{array}$ \\
\hline $\begin{array}{l}\text { HOHMANN, Ana } \\
\text { Carolina Cavalcanti }\end{array}$ & $\begin{array}{l}\text { Contratos de programa na } \\
\text { Lei federal n. 11107/05 }\end{array}$ & 2011 & $\begin{array}{l}\text { Dissertação } \\
\text { de mestrado }\end{array}$ & $\begin{array}{l}\text { Gustavo } \\
\text { Henrique } \\
\text { Justino de } \\
\text { Oliveira }\end{array}$ \\
\hline $\begin{array}{l}\text { CARVALHAES } \\
\text { NETO, Eduardo } \\
\text { Hayden }\end{array}$ & $\begin{array}{l}\text { Contratos } \text { privados da } \\
\text { administração pública: uma } \\
\text { análise do regime jurídico } \\
\text { aplicável }\end{array}$ & 2011 & $\begin{array}{l}\text { Tese de } \\
\text { doutorado }\end{array}$ & $\begin{array}{l}\text { Edmir Netto de } \\
\text { Araújo }\end{array}$ \\
\hline $\begin{array}{l}\text { GENOSO, } \\
\text { Gianfrancesco }\end{array}$ & $\begin{array}{l}\text { Princípio da continuidade do } \\
\text { serviço público }\end{array}$ & 2011 & $\begin{array}{l}\text { Dissertação } \\
\text { de mestrado }\end{array}$ & Odete Medauar \\
\hline OLBERTZ, Karlin & Operação urbana consorciada & 2011 & $\begin{array}{l}\text { Dissertação } \\
\text { de mestrado }\end{array}$ & Odete Medauar \\
\hline $\begin{array}{l}\text { TEDESCHI, } \\
\text { Patrícia Pereira }\end{array}$ & $\begin{array}{l}\text { Inovação tecnológica e direito } \\
\text { administrativo }\end{array}$ & 2011 & $\begin{array}{l}\text { Dissertação } \\
\text { de mestrado }\end{array}$ & $\begin{array}{l}\text { Edmir Netto de } \\
\text { Araújo }\end{array}$ \\
\hline $\begin{array}{l}\text { FRANÇA, Maria } \\
\text { Adelaide de Campos }\end{array}$ & $\begin{array}{l}\text { Parcerias público-privadas: } \\
\text { repartição objetiva de riscos }\end{array}$ & 2011 & $\begin{array}{c}\text { Tese de } \\
\text { doutorado }\end{array}$ & $\begin{array}{l}\text { Maria Sylvia } \\
\text { Zanella Di } \\
\text { Pietro }\end{array}$ \\
\hline $\begin{array}{l}\text { GUIMARÃES, } \\
\text { Bernardo Strobel }\end{array}$ & $\begin{array}{llll}\text { O exercício } & \text { da } & \text { função } \\
\text { administrativa } & \text { e } & \text { o } & \text { direito } \\
\text { privado } & & & \end{array}$ & 2011 & $\begin{array}{c}\text { Tese de } \\
\text { doutorado }\end{array}$ & $\begin{array}{l}\text { Maria Sylvia } \\
\text { Zanella Di } \\
\text { Pietro }\end{array}$ \\
\hline $\begin{array}{l}\text { SCHIRATO, Vitor } \\
\text { Rhein }\end{array}$ & $\begin{array}{l}\text { A noção de serviço público } \\
\text { em regime de competição }\end{array}$ & 2011 & $\begin{array}{c}\text { Tese de } \\
\text { doutorado }\end{array}$ & $\begin{array}{l}\text { Floriano de } \\
\text { Azevedo } \\
\text { Marques Neto }\end{array}$ \\
\hline $\begin{array}{l}\text { FRANCO, Marcos } \\
\text { Roberto }\end{array}$ & $\begin{array}{l}\text { Opoder de polícia no contexto } \\
\text { atual }\end{array}$ & 2012 & $\begin{array}{l}\text { Dissertação } \\
\text { de mestrado }\end{array}$ & $\begin{array}{l}\text { Edmir Netto de } \\
\text { Araújo }\end{array}$ \\
\hline $\begin{array}{l}\text { OLIVEIRA, Beatriz } \\
\text { Lancia Noronha de }\end{array}$ & $\begin{array}{l}\text { A arbitragem nos contratos de } \\
\text { parceria público-privada }\end{array}$ & 2012 & $\begin{array}{l}\text { Dissertação } \\
\text { de mestrado }\end{array}$ & $\begin{array}{l}\text { Gustavo } \\
\text { Henrique } \\
\text { Justino de } \\
\text { Oliveira }\end{array}$ \\
\hline $\begin{array}{l}\text { TOGNETTI, } \\
\text { Eduardo }\end{array}$ & $\begin{array}{llr}\text { Os limites } & \text { do } & \text { poder } \\
\text { discricionário } & & \text { da } \\
\text { administração } & & \text { pública } \\
\text { na imposição de } & \text { sanções } \\
\text { administrativas } & \text { - } & \text { análise } \\
\text { das sanções aplicáveis pelo } \\
\text { Banco Central do Brasil }\end{array}$ & 2012 & $\begin{array}{l}\text { Dissertação } \\
\text { de mestrado }\end{array}$ & $\begin{array}{l}\text { Maria Sylvia } \\
\text { Zanella Di } \\
\text { Pietro }\end{array}$ \\
\hline
\end{tabular}




\begin{tabular}{|c|c|c|c|c|}
\hline $\begin{array}{l}\text { BARROS, Laura } \\
\text { Mendes Amando de }\end{array}$ & $\begin{array}{l}\text { Participação popular, os } \\
\text { Conselhos Municipais } \\
\text { dos direitos da criança e } \\
\text { adolescente e os convênios } \\
\text { da administração com o } \\
\text { terceiro setor na área da } \\
\text { infância e juventude }\end{array}$ & 2012 & $\begin{array}{l}\text { Dissertação } \\
\text { de mestrado }\end{array}$ & $\begin{array}{l}\text { Gustavo } \\
\text { Henrique } \\
\text { Justino de } \\
\text { Oliveira }\end{array}$ \\
\hline $\begin{array}{l}\text { COSCIONE, } \\
\text { Milene Louise Renée }\end{array}$ & $\begin{array}{l}\text { A discricionariedade no } \\
\text { processo decisório da Agência } \\
\text { Nacional de Telecomunicações } \\
\text {-Anatel }\end{array}$ & 2012 & $\begin{array}{l}\text { Dissertação } \\
\text { de mestrado }\end{array}$ & $\begin{array}{l}\text { Floriano de } \\
\text { Azevedo } \\
\text { Marques Neto }\end{array}$ \\
\hline $\begin{array}{l}\text { CURY NETO, } \\
\text { Michel }\end{array}$ & $\begin{array}{l}\text { A competência fiscalizatória } \\
\text { prévia do tribunal de contas } \\
\text { nas licitações públicas }\end{array}$ & 2012 & $\begin{array}{l}\text { Dissertação } \\
\text { de mestrado }\end{array}$ & Odete Medauar \\
\hline $\begin{array}{l}\text { IKENAGA, Ana } \\
\text { Lúcia }\end{array}$ & $\begin{array}{l}\text { A atribuição de nome como } \\
\text { modo de exploração de bens } \\
\text { públicos }\end{array}$ & 2012 & $\begin{array}{l}\text { Dissertação } \\
\text { de mestrado }\end{array}$ & $\begin{array}{l}\text { Floriano de } \\
\text { Azevedo } \\
\text { Marques Neto }\end{array}$ \\
\hline $\begin{array}{l}\text { MESQUITA, } \\
\text { Clarissa Ferreira de } \\
\text { Melo }\end{array}$ & $\begin{array}{l}\text { O regime jurídico do setor } \\
\text { postal desafios contemporâneos } \\
\text { e perspectivasparao setor }\end{array}$ & 2012 & $\begin{array}{l}\text { Dissertação } \\
\text { de mestrado }\end{array}$ & $\begin{array}{l}\text { Floriano de } \\
\text { Azevedo } \\
\text { Marques Neto }\end{array}$ \\
\hline $\begin{array}{l}\text { GALVÃO, Ciro di } \\
\text { Benatti }\end{array}$ & $\begin{array}{lr}\text { Parâmetros } & \text { institucionais } \\
\text { para a } & \text { racionalidade } \\
\text { administrativa } & \text { local } \\
\text { contemporânea } & \end{array}$ & 2012 & $\begin{array}{l}\text { Dissertação } \\
\text { de mestrado }\end{array}$ & $\begin{array}{l}\text { Gustavo } \\
\text { Henrique } \\
\text { Justino de } \\
\text { Oliveira }\end{array}$ \\
\hline $\begin{array}{l}\text { BREGA, José } \\
\text { Fernando Ferreira }\end{array}$ & $\begin{array}{l}\text { Governo eletrônico e direito } \\
\text { administrativo }\end{array}$ & 2012 & $\begin{array}{c}\text { Tese de } \\
\text { doutorado }\end{array}$ & Odete Medauar \\
\hline
\end{tabular}




\section{ANEXO 2}

- $2013-2020$

\begin{tabular}{|c|c|c|c|c|}
\hline $\begin{array}{l}\text { PEDREIRA, Ana } \\
\text { Maria }\end{array}$ & $\begin{array}{l}\text { Responsabilidade do Estado } \\
\text { por omissão: prevenção, } \\
\text { precaução e controle }\end{array}$ & 2013 & $\begin{array}{l}\text { Dissertação } \\
\text { de mestrado }\end{array}$ & $\begin{array}{l}\text { Edmir Netto de } \\
\text { Araújo }\end{array}$ \\
\hline $\begin{array}{l}\text { JURKSAITIS, } \\
\text { Guilherme Jardim }\end{array}$ & $\begin{array}{l}\text { Dever de licitar: o caso da } \\
\text { contratação direta de serviços } \\
\text { advocatícios }\end{array}$ & 2013 & $\begin{array}{l}\text { Dissertação } \\
\text { de mestrado }\end{array}$ & $\begin{array}{l}\text { Fernando Dias } \\
\text { Menezes de } \\
\text { Almeida }\end{array}$ \\
\hline $\begin{array}{l}\text { CUNHA FILHO, } \\
\text { Alexandre Jorge } \\
\text { Carneiro da }\end{array}$ & $\begin{array}{l}\text { Delegação do poder de } \\
\text { polícia a entes privados }\end{array}$ & 2013 & $\begin{array}{l}\text { Dissertação } \\
\text { de mestrado }\end{array}$ & Odete Medauar \\
\hline $\begin{array}{l}\text { NASCIMENTO, } \\
\text { Mariana Chiesa } \\
\text { Gouveia }\end{array}$ & $\begin{array}{l}\text { O direito administrativo } \\
\text { da política pública de } \\
\text { regularização fundiária de } \\
\text { interesse social nas cidades } \\
\text { brasileiras }\end{array}$ & 2013 & $\begin{array}{l}\text { Dissertação } \\
\text { de mestrado }\end{array}$ & $\begin{array}{l}\text { Floriano de } \\
\text { Azevedo } \\
\text { Marques Neto }\end{array}$ \\
\hline $\begin{array}{l}\text { CUNHA, Carlos } \\
\text { Eduardo Bergamini da }\end{array}$ & $\begin{array}{l}\text { A } \\
\text { como vetor objetivo de } \\
\text { restrição à intervenção } \\
\text { regulatória do Estado na } \\
\text { economia: definição e } \\
\text { instrumentalização }\end{array}$ & 2013 & $\begin{array}{l}\text { Dissertação } \\
\text { de mestrado }\end{array}$ & $\begin{array}{l}\text { Floriano de } \\
\text { Azevedo } \\
\text { Marques Neto }\end{array}$ \\
\hline $\begin{array}{l}\text { REISDORFER, } \\
\text { Guilherme Dias }\end{array}$ & $\begin{array}{l}\text { Atuação privada na atividade } \\
\text { urbanística: planejamento e } \\
\text { contratualização }\end{array}$ & 2013 & $\begin{array}{l}\text { Dissertação } \\
\text { de mestrado }\end{array}$ & $\begin{array}{l}\text { Floriano de } \\
\text { Azevedo } \\
\text { Marques Neto }\end{array}$ \\
\hline MARQUES, Marcelo & $\begin{array}{l}\text { Participação popular na } \\
\text { administração pública e } \\
\text { os deveres fundamentais: } \\
\text { a face oculta do direito de } \\
\text { participação }\end{array}$ & 2013 & $\begin{array}{l}\text { Dissertação } \\
\text { de mestrado }\end{array}$ & $\begin{array}{l}\text { Gustavo } \\
\text { Henrique } \\
\text { Justino de } \\
\text { Oliveira }\end{array}$ \\
\hline $\begin{array}{l}\text { VARELLA, Guilherme } \\
\text { Rosa }\end{array}$ & $\begin{array}{l}\text { Plano Nacional de Cultura: } \\
\text { elaboração, desenvolvimento } \\
\text { e condições de eficácia }\end{array}$ & 2013 & $\begin{array}{l}\text { Dissertação } \\
\text { de mestrado }\end{array}$ & Odete Medauar \\
\hline $\begin{array}{l}\text { CAGGIANO, Alvaro } \\
\text { Theodor Herman } \\
\text { Salem }\end{array}$ & $\begin{array}{l}\text { Tratamento das nulidades no } \\
\text { processo administrativo }\end{array}$ & 2013 & $\begin{array}{l}\text { Dissertação } \\
\text { de mestrado }\end{array}$ & $\begin{array}{l}\text { Edmir Netto de } \\
\text { Araújo }\end{array}$ \\
\hline $\begin{array}{l}\text { SANTOS, Fábio } \\
\text { Gomes dos }\end{array}$ & $\begin{array}{l}\text { Audiências públicas no } \\
\text { direito brasileiro: perfil } \\
\text { dogmático e funções } \\
\text { desempenhadas }\end{array}$ & 2013 & $\begin{array}{l}\text { Dissertação } \\
\text { de mestrado }\end{array}$ & $\begin{array}{l}\text { Gustavo } \\
\text { Henrique } \\
\text { Justino de } \\
\text { Oliveira }\end{array}$ \\
\hline
\end{tabular}




\begin{tabular}{|c|c|c|c|c|}
\hline $\begin{array}{l}\text { SALIONE, Beatriz } \\
\text { Camasmie Curiati }\end{array}$ & $\begin{array}{l}\text { Administração Pública por } \\
\text { resultados e os contratos } \\
\text { de gestão: um modelo } \\
\text { de avaliação para as } \\
\text { organizações sociais do } \\
\text { Estado de São Paulo }\end{array}$ & 2013 & $\begin{array}{l}\text { Dissertação } \\
\text { de mestrado }\end{array}$ & $\begin{array}{l}\text { Gustavo } \\
\text { Henrique } \\
\text { Justino de } \\
\text { Oliveira }\end{array}$ \\
\hline $\begin{array}{l}\text { BARRETO, Dora } \\
\text { Maria Vendramini }\end{array}$ & Prescrição administrativa & 2013 & $\begin{array}{c}\text { Tese de } \\
\text { doutorado }\end{array}$ & $\begin{array}{l}\text { Edmir Netto de } \\
\text { Araújo }\end{array}$ \\
\hline $\begin{array}{l}\text { GOMES, Wilton Luis } \\
\text { da Silva }\end{array}$ & $\begin{array}{l}\text { Articulações entre os setores } \\
\text { público e privado em matéria } \\
\text { urbanística }\end{array}$ & 2013 & $\begin{array}{c}\text { Tese de } \\
\text { doutorado }\end{array}$ & $\begin{array}{l}\text { Maria Sylvia } \\
\text { Zanella Di } \\
\text { Pietro }\end{array}$ \\
\hline $\begin{array}{l}\text { PIRES, Gabriel Lino } \\
\text { de Paula }\end{array}$ & $\begin{array}{l}\text { Dinamicidade do controle } \\
\text { jurisdicional sobre a } \\
\text { Administração } \\
\text { a ampliação do âmblica: } \\
\text { de controle decorrente da } \\
\text { evolução do Direito brasileiro }\end{array}$ & 2014 & $\begin{array}{l}\text { Dissertação } \\
\text { de mestrado }\end{array}$ & $\begin{array}{l}\text { Fernando Dias } \\
\text { Menezes de } \\
\text { Almeida }\end{array}$ \\
\hline $\begin{array}{l}\text { MIGUEL, Luiz Felipe } \\
\text { Hadlich }\end{array}$ & $\begin{array}{l}\text { A remuneração do particular } \\
\text { na execução de atividades } \\
\text { públicas }\end{array}$ & 2014 & $\begin{array}{c}\text { Tese de } \\
\text { doutorado }\end{array}$ & Odete Medauar \\
\hline $\begin{array}{l}\text { ANGIOLUCCI, Maria } \\
\text { de Lurdes Aparecida } \\
\text { Trujillo }\end{array}$ & $\begin{array}{l}\text { O controle jurisdicional } \\
\text { dos atos administrativos } \\
\text { discricionários }\end{array}$ & 2014 & $\begin{array}{l}\text { Dissertação } \\
\text { de mestrado }\end{array}$ & $\begin{array}{l}\text { Edmir Netto de } \\
\text { Araújo }\end{array}$ \\
\hline $\begin{array}{l}\text { GHIDETTI, Luiz } \\
\text { Gustavo Casillo }\end{array}$ & $\begin{array}{l}\text { Improbidade Administrativa } \\
\text { e a figura dos terceiros }\end{array}$ & 2014 & $\begin{array}{l}\text { Dissertação } \\
\text { de mestrado }\end{array}$ & $\begin{array}{l}\text { Edmir Netto de } \\
\text { Araújo }\end{array}$ \\
\hline $\begin{array}{l}\text { MEIRELES, Renata } \\
\text { Nadalin }\end{array}$ & $\begin{array}{l}\text { A parceria público-privada } \\
\text { como instrumento de } \\
\text { urbanização e remodelação } \\
\text { urbana }\end{array}$ & 2014 & $\begin{array}{l}\text { Dissertação } \\
\text { de mestrado }\end{array}$ & $\begin{array}{l}\text { Fernando Dias } \\
\text { Menezes de } \\
\text { Almeida }\end{array}$ \\
\hline $\begin{array}{l}\text { FERRAZ, Ágata } \\
\text { Bobbio Ferraz }\end{array}$ & $\begin{array}{l}\text { Políticas públicas e o papel } \\
\text { do Estado na efetivação de } \\
\text { direitos constitucionais }\end{array}$ & 2014 & $\begin{array}{l}\text { Dissertação } \\
\text { de mestrado }\end{array}$ & $\begin{array}{l}\text { Fernando Dias } \\
\text { Menezes de } \\
\text { Almeida } \\
\end{array}$ \\
\hline $\begin{array}{l}\text { GARÓFANO, Rafael } \\
\text { Roque }\end{array}$ & $\begin{array}{l}\text { A consensualidade nos } \\
\text { contratos administrativos: do } \\
\text { regime estatutário à parceria } \\
\text { contratual }\end{array}$ & 2014 & $\begin{array}{l}\text { Dissertação } \\
\text { de mestrado }\end{array}$ & $\begin{array}{l}\text { Floriano de } \\
\text { Azevedo } \\
\text { Marques Neto }\end{array}$ \\
\hline $\begin{array}{l}\text { SCHWIND, Rafael } \\
\text { Wallbach }\end{array}$ & $\begin{array}{l}\text { Participação estatal em } \\
\text { empresas privadas: as } \\
\text { empresas público-privadas }\end{array}$ & 2014 & $\begin{array}{c}\text { Tese de } \\
\text { doutorado }\end{array}$ & $\begin{array}{l}\text { Maria Sylvia } \\
\text { Zanella Di } \\
\text { Pietro }\end{array}$ \\
\hline KLEIN, Aline Lícia & $\begin{array}{l}\text { Exercício de atividades de } \\
\text { polícia administrativa por } \\
\text { entidades privadas }\end{array}$ & 2014 & $\begin{array}{c}\text { Tese de } \\
\text { doutorado }\end{array}$ & $\begin{array}{l}\text { Maria Sylvia } \\
\text { Zanella Di } \\
\text { Pietro }\end{array}$ \\
\hline
\end{tabular}




\begin{tabular}{|c|c|c|c|c|}
\hline FERRO, Murilo Ruiz & $\begin{array}{l}\text { Pontos de convergência } \\
\text { entre as teses doutrinárias } \\
\text { brasileiras quanto ao } \\
\text { princípio da supremacia do } \\
\text { interesse público sobre o } \\
\text { particular }\end{array}$ & 2014 & $\begin{array}{l}\text { Dissertação } \\
\text { de mestrado }\end{array}$ & $\begin{array}{l}\text { Maria Sylvia } \\
\text { Zanella Di } \\
\text { Pietro }\end{array}$ \\
\hline $\begin{array}{l}\text { OLIVEIRA, André } \\
\text { Tito da Motta }\end{array}$ & $\begin{array}{l}\text { Terceiro Setor e controle dos } \\
\text { Tribunais de Contas: entre os } \\
\text { lindes da transparência e da } \\
\text { eficiência }\end{array}$ & 2014 & $\begin{array}{l}\text { Dissertação } \\
\text { de mestrado }\end{array}$ & $\begin{array}{l}\text { Gustavo } \\
\text { Henrique } \\
\text { Justino de } \\
\text { Oliveira }\end{array}$ \\
\hline $\begin{array}{l}\text { SILVA, Renata Gomes } \\
\text { da }\end{array}$ & $\begin{array}{l}\text { Coordenação entre os entes } \\
\text { federados nas políticas } \\
\text { públicas de habitação: } \\
\text { análise do Fundo Nacional de } \\
\text { Habitação de Interesse Social }\end{array}$ & 2014 & $\begin{array}{l}\text { Dissertação } \\
\text { de mestrado }\end{array}$ & $\begin{array}{l}\text { Fernando Dias } \\
\text { Menezes de } \\
\text { Almeida }\end{array}$ \\
\hline MONTEIRO, Vítor & $\begin{array}{l}\text { O Contrato de Gestão como } \\
\text { tipo contratual federativo }\end{array}$ & 2014 & $\begin{array}{l}\text { Dissertação } \\
\text { de mestrado }\end{array}$ & $\begin{array}{l}\text { Fernando Dias } \\
\text { Menezes de } \\
\text { Almeida }\end{array}$ \\
\hline $\begin{array}{l}\text { BATISTA, Emanuel } \\
\text { Pedro Fernandes }\end{array}$ & $\begin{array}{l}\text { Agências reguladoras e } \\
\text { controle administrativo: } \\
\text { uma análise da possibilidade } \\
\text { de interposição de recurso } \\
\text { hierárquico impróprio no } \\
\text { âmbito decisório das agências } \\
\text { nacionais de regulação }\end{array}$ & 2014 & $\begin{array}{l}\text { Dissertação } \\
\text { de mestrado }\end{array}$ & $\begin{array}{l}\text { Maria Sylvia } \\
\text { Zanella Di } \\
\text { Pietro }\end{array}$ \\
\hline $\begin{array}{l}\text { SOUZA, Rafael } \\
\text { Soares }\end{array}$ & $\begin{array}{llr}\text { Sistemas de controle } \\
\text { jurisdicional } & \text { da } \\
\text { Administração Pública: } & \text { o } \\
\text { modelo brasileiro } & \end{array}$ & 2014 & $\begin{array}{l}\text { Dissertação } \\
\text { de mestrado }\end{array}$ & $\begin{array}{l}\text { Fernando Dias } \\
\text { Menezes de } \\
\text { Almeida }\end{array}$ \\
\hline $\begin{array}{l}\text { ANDRADE, Carolina } \\
\text { Castro }\end{array}$ & $\begin{array}{lr}\text { Os limites do poder } \\
\text { discricionário } & \\
\text { administrador } & \text { e } \\
\text { discricionariedade } & \text { como } \\
\text { limite do controle judicial } \\
\text { da Administração Pública: } \\
\text { novos horizontes para a } \\
\text { argumentação jurídica e } \\
\text { sua recepção nos tribunais } \\
\text { brasileiros }\end{array}$ & 2014 & $\begin{array}{l}\text { Dissertação } \\
\text { de mestrado }\end{array}$ & $\begin{array}{l}\text { Fernando Dias } \\
\text { Menezes de } \\
\text { Almeida }\end{array}$ \\
\hline $\begin{array}{l}\text { CARVALHO, Paulo } \\
\text { de Tarso Bilard de }\end{array}$ & $\begin{array}{l}\text { O conceito jurídico do } \\
\text { princípio de impessoalidade } \\
\text { no direito administrativo } \\
\text { brasileiro: uma releitura }\end{array}$ & 2014 & $\begin{array}{l}\text { Dissertação } \\
\text { de mestrado }\end{array}$ & $\begin{array}{l}\text { Maria Sylvia } \\
\text { Zanella Di } \\
\text { Pietro }\end{array}$ \\
\hline
\end{tabular}




\begin{tabular}{|c|c|c|c|c|}
\hline $\begin{array}{l}\text { PALMA, Juliana } \\
\text { Bonacorsi de }\end{array}$ & $\begin{array}{l}\text { Atividade normativa da } \\
\text { administração pública: } \\
\text { estudo do processo } \\
\text { regulatório normativo }\end{array}$ & 2014 & $\begin{array}{c}\text { Tese de } \\
\text { doutorado }\end{array}$ & $\begin{array}{l}\text { Floriano de } \\
\text { Azevedo } \\
\text { Marques Neto }\end{array}$ \\
\hline $\begin{array}{l}\text { LOUREIRO FILHO, } \\
\text { Lair da Silva }\end{array}$ & $\begin{array}{l}\text { A competência do Município } \\
\text { da zona costeira urbana }\end{array}$ & 2014 & $\begin{array}{l}\text { Tese de } \\
\text { doutorado }\end{array}$ & Odete Medauar \\
\hline ISSA, Rafael Hamze & $\begin{array}{l}\text { O controle judicial dos atos } \\
\text { normativos das agências } \\
\text { reguladoras }\end{array}$ & 2015 & $\begin{array}{l}\text { Dissertação } \\
\text { de mestrado }\end{array}$ & $\begin{array}{l}\text { Floriano de } \\
\text { Azevedo } \\
\text { Marques Neto }\end{array}$ \\
\hline $\begin{array}{l}\text { ALTALE, Marcela de } \\
\text { Lima }\end{array}$ & $\begin{array}{l}\text { As garantias outorgadas } \\
\text { por empresas estatais e } \\
\text { concessionárias de serviços } \\
\text { publicos em projetos de } \\
\text { financiamento }\end{array}$ & 2015 & $\begin{array}{l}\text { Dissertação } \\
\text { de mestrado }\end{array}$ & $\begin{array}{l}\text { Edmir Netto de } \\
\text { Araújo }\end{array}$ \\
\hline $\begin{array}{l}\text { VIEIRA, Livia } \\
\text { Wanderley de B. M. }\end{array}$ & $\begin{array}{l}\text { Manifestação de interesse } \\
\text { e propostas não solicitadas: } \\
\text { mecanismos de contribuição } \\
\text { para o alcance dos fins } \\
\text { de interesse público nas } \\
\text { parcerias público-privadas }\end{array}$ & 2015 & $\begin{array}{c}\text { Tese de } \\
\text { doutorado }\end{array}$ & $\begin{array}{l}\text { Floriano de } \\
\text { Azevedo } \\
\text { Marques Neto }\end{array}$ \\
\hline ZAGO, Marina Fontão & $\begin{array}{l}\text { Uso derivado da contratação } \\
\text { administrativa: direcionando } \\
\text { o poder de compra estatal } \\
\text { para a execução de políticas } \\
\text { públicas }\end{array}$ & 2015 & $\begin{array}{c}\text { Tese de } \\
\text { doutorado }\end{array}$ & $\begin{array}{l}\text { Floriano de } \\
\text { Azevedo } \\
\text { Marques Neto }\end{array}$ \\
\hline $\begin{array}{l}\text { CARVALHO, Juliane } \\
\text { Erthal de }\end{array}$ & 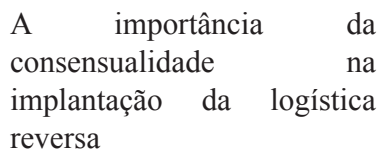 & 2015 & $\begin{array}{l}\text { Dissertação } \\
\text { de mestrado }\end{array}$ & $\begin{array}{l}\text { Floriano de } \\
\text { Azevedo } \\
\text { Marques Neto }\end{array}$ \\
\hline $\begin{array}{l}\text { BARELLI, Amanda } \\
\text { Fabbri }\end{array}$ & $\begin{array}{l}\text { A aplicabilidade da teoria } \\
\text { da desconsideração da } \\
\text { personalidade jurídica ao } \\
\text { processo administrativo: uma } \\
\text { análise sob a perspectiva do } \\
\text { direito antitruste }\end{array}$ & 2015 & $\begin{array}{l}\text { Dissertação } \\
\text { de mestrado }\end{array}$ & $\begin{array}{l}\text { Gustavo } \\
\text { Henrique } \\
\text { Justino de } \\
\text { Oliveira }\end{array}$ \\
\hline $\begin{array}{l}\text { BASTOS, Aline Maria } \\
\text { Dias }\end{array}$ & $\begin{array}{l}\text { Regime disciplinar do } \\
\text { servidor público temporário }\end{array}$ & 2015 & $\begin{array}{c}\text { Tese de } \\
\text { doutorado }\end{array}$ & $\begin{array}{l}\text { Edmir Netto de } \\
\text { Araújo }\end{array}$ \\
\hline $\begin{array}{l}\text { CUCINELLI, Otavio } \\
\text { Henrique Simão e }\end{array}$ & $\begin{array}{l}\text { Da aplicação do princípio da } \\
\text { insignificância aos atos da } \\
\text { improbidade administrativa }\end{array}$ & 2015 & $\begin{array}{l}\text { Dissertação } \\
\text { de mestrado }\end{array}$ & $\begin{array}{l}\text { Maria Sylvia } \\
\text { Zanella Di } \\
\text { Pietro }\end{array}$ \\
\hline $\begin{array}{l}\text { PINTO, Bruno Luis } \\
\text { Amorim }\end{array}$ & $\begin{array}{l}\text { O regime jurídico dos } \\
\text { contratos de cooperação } \\
\text { entre o Estado brasileiro e o } \\
\text { terceiro setor }\end{array}$ & 2015 & $\begin{array}{l}\text { Dissertação } \\
\text { de mestrado }\end{array}$ & $\begin{array}{l}\text { Maria Sylvia } \\
\text { Zanella Di } \\
\text { Pietro }\end{array}$ \\
\hline
\end{tabular}




\begin{tabular}{|c|c|c|c|c|}
\hline TOGNETTI, Eduardo & $\begin{array}{l}\text { Regime jurídico das } \\
\text { contratações feitas por } \\
\text { sociedades de economia } \\
\text { mista e por empresas públicas } \\
\text { exploradoras de atividade } \\
\text { econômica }\end{array}$ & 2015 & $\begin{array}{c}\text { Tese de } \\
\text { doutorado }\end{array}$ & $\begin{array}{l}\text { Maria Sylvia } \\
\text { Zanella Di } \\
\text { Pietro }\end{array}$ \\
\hline $\begin{array}{l}\text { CIAMPAGLIA, } \\
\text { Márcia Cristina } \\
\text { Nogueira }\end{array}$ & $\begin{array}{l}\text { Ato administrativo inválido e } \\
\text { restauração da legalidade }\end{array}$ & 2015 & $\begin{array}{l}\text { Dissertação } \\
\text { de mestrado }\end{array}$ & $\begin{array}{l}\text { Edmir Netto de } \\
\text { Araújo }\end{array}$ \\
\hline $\begin{array}{l}\text { RIBAS, Guilherme } \\
\text { Favaro Corvo }\end{array}$ & $\begin{array}{l}\text { A prova no processo } \\
\text { administrativo } \\
\text { investigação de cartel }\end{array}$ & 2015 & $\begin{array}{c}\text { Tese de } \\
\text { doutorado }\end{array}$ & Odete Medauar \\
\hline $\begin{array}{l}\text { FABRE, Flávia } \\
\text { Moraes Barros } \\
\text { Michele }\end{array}$ & $\begin{array}{l}\text { Função horizontal da } \\
\text { licitação e da contratação } \\
\text { administrativa }\end{array}$ & 2015 & $\begin{array}{c}\text { Tese de } \\
\text { doutorado }\end{array}$ & Odete Medauar \\
\hline $\begin{array}{l}\text { CARVALHO NETO, } \\
\text { Tarcisio Vieira de }\end{array}$ & $\begin{array}{l}\text { O princípio da } \\
\text { impessoalidade nas decisões } \\
\text { administrativas }\end{array}$ & 2015 & $\begin{array}{c}\text { Tese de } \\
\text { doutorado }\end{array}$ & Odete Medauar \\
\hline $\begin{array}{l}\text { RIBEIRO, Carlos } \\
\text { Vinícius Alves }\end{array}$ & $\begin{array}{l}\text { Ações estatais restritivas } \\
\text { de direitos individuais em } \\
\text { benefício dos próprios } \\
\text { titulares }\end{array}$ & 2015 & $\begin{array}{l}\text { Tese de } \\
\text { doutorado }\end{array}$ & $\begin{array}{l}\text { Maria Sylvia } \\
\text { Zanella Di } \\
\text { Pietro }\end{array}$ \\
\hline $\begin{array}{l}\text { FREITAS, Marina } \\
\text { Cardoso }\end{array}$ & $\begin{array}{llr}\text { As } & \text { características } \\
\text { contemporâneas } & \text { da } \\
\text { autorização nos serviços } \\
\text { regulados: estudo do regime } \\
\text { jurídico das atividades } \\
\text { autorizadas } & \end{array}$ & 2016 & $\begin{array}{l}\text { Dissertação } \\
\text { de mestrado }\end{array}$ & $\begin{array}{l}\text { Floriano de } \\
\text { Azevedo } \\
\text { Marques Neto }\end{array}$ \\
\hline MORENO, Maís & $\begin{array}{l}\text { O processo administrativo na } \\
\text { elaboração dos contratos de } \\
\text { PPP: abertura à participação }\end{array}$ & 2016 & $\begin{array}{l}\text { Dissertação } \\
\text { de mestrado }\end{array}$ & $\begin{array}{l}\text { Floriano de } \\
\text { Azevedo } \\
\text { Marques Neto }\end{array}$ \\
\hline $\begin{array}{l}\text { SALVO, Sílvia Helena } \\
\text { Picarelli Gonçalves } \\
\text { J. di }\end{array}$ & $\begin{array}{l}\text { O papel das agências } \\
\text { reguladoras na resolução de } \\
\text { conflitos }\end{array}$ & 2016 & $\begin{array}{l}\text { Dissertação } \\
\text { de mestrado }\end{array}$ & $\begin{array}{l}\text { Gustavo } \\
\text { Henrique } \\
\text { Justino de } \\
\text { Oliveira }\end{array}$ \\
\hline $\begin{array}{l}\text { MARQUES JÚNIOR, } \\
\text { José Jair }\end{array}$ & $\begin{array}{l}\text { Prorrogação de exploração de } \\
\text { concessão de serviço público: } \\
\text { proposta de sistematização } \\
\text { de um regime jurídico geral } \\
\text { aplicável a essa modalidade } \\
\text { impeditiva e modificativa da } \\
\text { extinção concessória }\end{array}$ & 2016 & $\begin{array}{l}\text { Dissertação } \\
\text { de mestrado }\end{array}$ & $\begin{array}{l}\text { Floriano de } \\
\text { Azevedo } \\
\text { Marques Neto }\end{array}$ \\
\hline
\end{tabular}




\begin{tabular}{|c|c|c|c|c|}
\hline $\begin{array}{l}\text { ZAGO, Marina } \\
\text { Augusta dos Santos }\end{array}$ & $\begin{array}{l}\text { Federalismo no Brasil } \\
\text { e na Alemanha: estudo } \\
\text { comparativo da repartição de } \\
\text { competências legislativas e } \\
\text { de execução }\end{array}$ & 2016 & $\begin{array}{l}\text { Tese de } \\
\text { doutorado }\end{array}$ & $\begin{array}{l}\text { Fernando Dias } \\
\text { Menezes de } \\
\text { Almeida }\end{array}$ \\
\hline $\begin{array}{l}\text { FERRAZ, André } \\
\text { Tavares }\end{array}$ & $\begin{array}{l}\text { Participação do usuário de } \\
\text { transporte público urbano na } \\
\text { administração pública }\end{array}$ & 2016 & $\begin{array}{l}\text { Dissertação } \\
\text { de mestrado }\end{array}$ & $\begin{array}{l}\text { Gustavo } \\
\text { Henrique } \\
\text { Justino de } \\
\text { Oliveira }\end{array}$ \\
\hline $\begin{array}{l}\text { ARAÚJO, Alexandra } \\
\text { Fuchs de }\end{array}$ & $\begin{array}{l}\text { Audiências públicas na } \\
\text { reforma do Plano Diretor da } \\
\text { Cidade de São Paulo: limites } \\
\text { da participação popular }\end{array}$ & 2016 & $\begin{array}{l}\text { Dissertação } \\
\text { de mestrado }\end{array}$ & $\begin{array}{l}\text { Gustavo } \\
\text { Henrique } \\
\text { Justino de } \\
\text { Oliveira }\end{array}$ \\
\hline $\begin{array}{l}\text { ROSILHO, André } \\
\text { Janjácomo }\end{array}$ & $\begin{array}{l}\text { Controle das contribuições } \\
\text { públicas pelo Tribunal de } \\
\text { Contas da União }\end{array}$ & 2016 & $\begin{array}{c}\text { Tese de } \\
\text { doutorado }\end{array}$ & $\begin{array}{l}\text { Floriano de } \\
\text { Azevedo } \\
\text { Marques Neto }\end{array}$ \\
\hline $\begin{array}{l}\text { HOHMANN, Ana } \\
\text { Carolina Cavalcanti }\end{array}$ & $\begin{array}{l}\text { O Direito administrativo } \\
\text { global e sua influência para o } \\
\text { desenvolvimento: Regulação } \\
\text { e segurança jurídica para o } \\
\text { ingresso de investimentos em } \\
\text { infraestrutura no Brasi }\end{array}$ & 2016 & $\begin{array}{l}\text { Tese de } \\
\text { doutorado }\end{array}$ & $\begin{array}{l}\text { Gustavo } \\
\text { Henrique } \\
\text { Justino de } \\
\text { Oliveira }\end{array}$ \\
\hline $\begin{array}{l}\text { LEISTER, Ana } \\
\text { Carolina Corrêa da } \\
\text { Costa }\end{array}$ & $\begin{array}{l}\text { A regulação na indústria } \\
\text { do petróleo: uma análise } \\
\text { da regulação do segmento } \\
\text { de E\&P no país a partir do } \\
\text { paradigma da segurança } \\
\text { energética }\end{array}$ & 2016 & $\begin{array}{c}\text { Tese de } \\
\text { doutorado }\end{array}$ & $\begin{array}{l}\text { Gustavo } \\
\text { Henrique } \\
\text { Justino de } \\
\text { Oliveira }\end{array}$ \\
\hline $\begin{array}{l}\text { NASCIMENTO, } \\
\text { Mariana Chiesa } \\
\text { Gouveia }\end{array}$ & $\begin{array}{l}\text { Função administrativa } \\
\text { na regulação do uso e da } \\
\text { ocupação do espaço urbano }\end{array}$ & 2017 & $\begin{array}{c}\text { Tese de } \\
\text { doutorado }\end{array}$ & $\begin{array}{l}\text { Floriano de } \\
\text { Azevedo } \\
\text { Marques Neto }\end{array}$ \\
\hline $\begin{array}{l}\text { LOBO FILHO, } \\
\text { Fernando Rissoli }\end{array}$ & $\begin{array}{l}\text { A Lei Anticorrupção e o } \\
\text { regime jurídico do direito } \\
\text { administrativo sancionador }\end{array}$ & 2017 & $\begin{array}{l}\text { Dissertação } \\
\text { de mestrado }\end{array}$ & $\begin{array}{l}\text { Maria Sylvia } \\
\text { Zanella Di } \\
\text { Pietro } \\
\end{array}$ \\
\hline $\begin{array}{l}\text { SCHIEFLER, Gustavo } \\
\text { Henrique Carvalho }\end{array}$ & $\begin{array}{l}\text { O processo administrativo } \\
\text { participativo consensual } \\
\text { como fonte de legitimidade } \\
\text { dos atos administrativos e da } \\
\text { administração pública }\end{array}$ & 2017 & $\begin{array}{l}\text { Tese de } \\
\text { doutorado }\end{array}$ & $\begin{array}{l}\text { Gustavo } \\
\text { Henrique } \\
\text { Justino de } \\
\text { Oliveira }\end{array}$ \\
\hline $\begin{array}{l}\text { CESAR, Roberta } \\
\text { Bortot }\end{array}$ & $\begin{array}{l}\text { Regulação dos serviços } \\
\text { públicos: o caso da ANEEL }\end{array}$ & 2017 & $\begin{array}{l}\text { Dissertação } \\
\text { de mestrado }\end{array}$ & $\begin{array}{l}\text { Vitor Rhein } \\
\text { Schirato }\end{array}$ \\
\hline $\begin{array}{l}\text { TAVARES, Tiaia } \\
\text { Mendes }\end{array}$ & $\begin{array}{l}\text { Positivação de limites ao } \\
\text { desenvolvimento de políticas } \\
\text { públicas e seu controle } \\
\text { judicia }\end{array}$ & 2017 & $\begin{array}{l}\text { Dissertação } \\
\text { de mestrado }\end{array}$ & $\begin{array}{l}\text { Maria Sylvia } \\
\text { Zanella Di } \\
\text { Pietro }\end{array}$ \\
\hline
\end{tabular}




\begin{tabular}{|c|c|c|c|c|}
\hline $\begin{array}{l}\text { CUNHA FILHO, } \\
\text { Alexandre Jorge } \\
\text { Carneiro da }\end{array}$ & \begin{tabular}{|lr} 
Governança & pública \\
na & administração \\
contemporânea
\end{tabular} & 2017 & $\begin{array}{c}\text { Tese de } \\
\text { doutorado }\end{array}$ & $\begin{array}{l}\text { Vitor Rhein } \\
\text { Schirato }\end{array}$ \\
\hline $\begin{array}{l}\text { CARVALHO, } \\
\text { Guilherme Siqueira de }\end{array}$ & $\begin{array}{lccc}\text { O direito } & \text { de } & \text { acesso à } \\
\text { informação } & \mathrm{e} & \mathrm{o} & \text { sigilo } \\
\text { econômico } & \text { nas } & \text { empresas } \\
\text { estatais } & & \end{array}$ & 2017 & $\begin{array}{l}\text { Dissertação } \\
\text { de mestrado }\end{array}$ & $\begin{array}{l}\text { Fernando Dias } \\
\text { Menezes de } \\
\text { Almeida }\end{array}$ \\
\hline $\begin{array}{l}\text { MIRAGAYA, Rodrigo } \\
\text { Bracet }\end{array}$ & $\begin{array}{l}\text { A sistemarização dos meios } \\
\text { de manifestação de vontade } \\
\text { no direito administrativo } \\
\text { e sua utilização como } \\
\text { instrumentos de gestão }\end{array}$ & 2017 & $\begin{array}{c}\text { Tese de } \\
\text { doutorado }\end{array}$ & $\begin{array}{l}\text { Floriano de } \\
\text { Azevedo } \\
\text { Marques Neto }\end{array}$ \\
\hline $\begin{array}{l}\text { BARROS, Laura } \\
\text { Mendes Amando de }\end{array}$ & $\begin{array}{l}\text { A auditoria cidadã como } \\
\text { instrumento de mensuração } \\
\text { da qualidade da democracia } \\
\text { administrativa no município } \\
\text { de São Paulo }\end{array}$ & 2017 & $\begin{array}{c}\text { Tese de } \\
\text { doutorado }\end{array}$ & $\begin{array}{l}\text { Gustavo } \\
\text { Henrique } \\
\text { Justino de } \\
\text { Oliveira }\end{array}$ \\
\hline $\begin{array}{l}\text { JUNQUEIRA, André } \\
\text { Rodrigues }\end{array}$ & $\begin{array}{l}\text { Arbitragem e administração } \\
\text { pública: estudo de caso sobre } \\
\text { as repercussões econômicas } \\
\text { nas parcerias públicos- } \\
\text { privada do estado de São } \\
\text { Paulo }\end{array}$ & 2017 & $\begin{array}{l}\text { Dissertação } \\
\text { de mestrado }\end{array}$ & $\begin{array}{l}\text { Gustavo } \\
\text { Henrique } \\
\text { Justino de } \\
\text { Oliveira }\end{array}$ \\
\hline $\begin{array}{l}\text { VIANA, Camila } \\
\text { Rocha Cunha }\end{array}$ & $\begin{array}{l}\text { Administração pública } \\
\text { contratual: o contrato como } \\
\text { instrumento de efetivação } \\
\text { de políticas públicas de } \\
\text { infraestrutura }\end{array}$ & 2017 & $\begin{array}{l}\text { Dissertação } \\
\text { de mestrado }\end{array}$ & $\begin{array}{l}\text { Vitor Rhein } \\
\text { Schirato }\end{array}$ \\
\hline $\begin{array}{l}\text { SOARES, Leonardo } \\
\text { Romano }\end{array}$ & $\begin{array}{l}\text { Controles sobre as } \\
\text { parcerias com organizações } \\
\text { da sociedade civil: } \\
\text { transparência, resultados e } \\
\text { participação social }\end{array}$ & 2017 & $\begin{array}{l}\text { Dissertação } \\
\text { de mestrado }\end{array}$ & $\begin{array}{l}\text { Fernando Dias } \\
\text { Menezes de } \\
\text { Almeida }\end{array}$ \\
\hline $\begin{array}{l}\text { PEDREIRA, Ana } \\
\text { Maria }\end{array}$ & $\begin{array}{l}\text { A regulação do ensino } \\
\text { superior brasileiro e a } \\
\text { necessidade de um novo } \\
\text { modelo }\end{array}$ & 2017 & $\begin{array}{c}\text { Tese de } \\
\text { doutorado }\end{array}$ & $\begin{array}{l}\text { Edmir Netto de } \\
\text { Araújo }\end{array}$ \\
\hline $\begin{array}{l}\text { CARDINALI, Adriana } \\
\text { Laporta }\end{array}$ & $\begin{array}{l}\text { Instrumentos de solução } \\
\text { de controvérsias no direito } \\
\text { concorrencial brasileiro }\end{array}$ & 2017 & $\begin{array}{c}\text { Tese de } \\
\text { doutorado }\end{array}$ & $\begin{array}{l}\text { Gustavo } \\
\text { Henrique } \\
\text { Justino de } \\
\text { Oliveira }\end{array}$ \\
\hline $\begin{array}{l}\text { MUNIZ, Cibele } \\
\text { Cristina Baldassa }\end{array}$ & $\begin{array}{l}\text { Participação democrática } \\
\text { na administração pública: } \\
\text { audiências e consultas } \\
\text { públicas na Lei } 9784 / 99\end{array}$ & 2018 & $\begin{array}{c}\text { Tese de } \\
\text { doutorado }\end{array}$ & $\begin{array}{l}\text { Edmir Netto de } \\
\text { Araújo }\end{array}$ \\
\hline
\end{tabular}




\begin{tabular}{|c|c|c|c|c|}
\hline $\begin{array}{l}\text { MELONCINI, Maria } \\
\text { Isabela Haro }\end{array}$ & $\begin{array}{l}\text { Gestão democrática na } \\
\text { elaboração do plano diretor: } \\
\text { o caso do Plano Diretor } \\
\text { Estratégico do Município de } \\
\text { São Paulo (Lei Municipal n } \\
\text { 16.050/2014) }\end{array}$ & 2018 & $\begin{array}{l}\text { Dissertação } \\
\text { de mestrado }\end{array}$ & $\begin{array}{l}\text { Fernando Dias } \\
\text { Menezes de } \\
\text { Almeida }\end{array}$ \\
\hline $\begin{array}{l}\text { LEFÉVRE, Mônica } \\
\text { Bandeira de Mello }\end{array}$ & $\begin{array}{l}\text { A vinculatividade e o controle } \\
\text { dos acordos substitutivos da } \\
\text { decisão administrativa }\end{array}$ & 2018 & $\begin{array}{c}\text { Dissertação } \\
\text { de mestrado }\end{array}$ & $\begin{array}{l}\text { Fernando Dias } \\
\text { Menezes de } \\
\text { Almeida }\end{array}$ \\
\hline $\begin{array}{l}\text { RODRIGUES, } \\
\text { Fernanda Esbizaro }\end{array}$ & $\begin{array}{l}\text { Instrumentos jurídicos de } \\
\text { atuação administrativa: } \\
\text { estudo comparado Brasil- } \\
\text { Alemanha }\end{array}$ & 2018 & $\begin{array}{l}\text { Dissertação } \\
\text { de mestrado }\end{array}$ & $\begin{array}{l}\text { Fernando Dias } \\
\text { Menezes de } \\
\text { Almeida }\end{array}$ \\
\hline $\begin{array}{l}\text { MERLOTTO, Nara } \\
\text { Carolina }\end{array}$ & 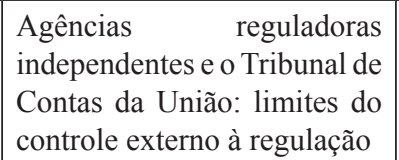 & 2018 & $\begin{array}{l}\text { Dissertação } \\
\text { de mestrado }\end{array}$ & $\begin{array}{l}\text { Floriano de } \\
\text { Azevedo } \\
\text { Marques Neto }\end{array}$ \\
\hline $\begin{array}{l}\text { ALENCAR, Letícia } \\
\text { Oliveira Lins de }\end{array}$ & \begin{tabular}{|l|} 
Uma releitura do equilíbrio \\
econômico-financeiro nas \\
concessões de serviço \\
público
\end{tabular} & 2018 & $\begin{array}{l}\text { Dissertação } \\
\text { de mestrado }\end{array}$ & $\begin{array}{l}\text { Rodrigo Pagani } \\
\text { de Souza }\end{array}$ \\
\hline $\begin{array}{l}\text { MOREIRA, Natalia } \\
\text { Rebello }\end{array}$ & $\begin{array}{l}\text { Atividade estatal de fomento } \\
\text { à inovação tecnológica em } \\
\text { empresas }\end{array}$ & 2018 & $\begin{array}{l}\text { Dissertação } \\
\text { de mestrado }\end{array}$ & $\begin{array}{l}\text { Marcos Augusto } \\
\text { Perez }\end{array}$ \\
\hline FAGALI, Bruno Jorge & $\begin{array}{l}\text { O acordo de leniência da } \\
\text { legislação anticorrupção } \\
\text { empresarial brasileira: o } \\
\text { difícil equilíbrio entre sua } \\
\text { utilidade e sua atividade }\end{array}$ & 2018 & $\begin{array}{l}\text { Dissertação } \\
\text { de mestrado }\end{array}$ & $\begin{array}{l}\text { Marcos Augusto } \\
\text { Perez }\end{array}$ \\
\hline $\begin{array}{l}\text { SAVIOLI, Anna } \\
\text { Beatriz }\end{array}$ & $\begin{array}{l}\text { Licitações como instrumento } \\
\text { do fomento estatal }\end{array}$ & 2018 & $\begin{array}{l}\text { Dissertação } \\
\text { de mestrado }\end{array}$ & $\begin{array}{l}\text { Marcos Augusto } \\
\text { Perez }\end{array}$ \\
\hline $\begin{array}{l}\text { ROBERTO, Luís } \\
\text { Fernando }\end{array}$ & $\begin{array}{l}\text { Simplificação administrativa: } \\
\text { o standard cost model } \\
\text { aplicado ao Brasil }\end{array}$ & 2018 & $\begin{array}{c}\text { Tese de } \\
\text { doutorado }\end{array}$ & $\begin{array}{l}\text { Rodrigo Pagani } \\
\text { de Souza }\end{array}$ \\
\hline $\begin{array}{l}\text { FRANCO, Marcos } \\
\text { Roberto }\end{array}$ & $\begin{array}{l}\text { A flexibilização do princípio } \\
\text { da supremacia do interesse } \\
\text { público diante da democracia } \\
\text { participativa }\end{array}$ & 2018 & $\begin{array}{c}\text { Tese de } \\
\text { doutorado }\end{array}$ & $\begin{array}{l}\text { Edmir Netto de } \\
\text { Araújo }\end{array}$ \\
\hline COSTA, Luisa Maffei & $\begin{array}{l}\text { O controle externo das } \\
\text { contratações diretas realizado } \\
\text { pelo Tribunal de Contas da } \\
\text { União: uma análise de sua } \\
\text { atuação a partir de casos } \\
\text { concretos }\end{array}$ & 2018 & $\begin{array}{l}\text { Dissertação } \\
\text { de mestrado }\end{array}$ & $\begin{array}{l}\text { Fernando Dias } \\
\text { Menezes de } \\
\text { Almeida }\end{array}$ \\
\hline
\end{tabular}




\begin{tabular}{|c|c|c|c|c|}
\hline $\begin{array}{l}\text { GALVÃO, Gabriel de } \\
\text { Mello }\end{array}$ & $\begin{array}{l}\text { Conceitos indeterminados, } \\
\text { remissões normativas e } \\
\text { interpretação sistemática } \\
\text { de obrigações contratuais e } \\
\text { regulatórias nas concessões } \\
\text { de utilidades públicas }\end{array}$ & 2018 & $\begin{array}{c}\text { Tese de } \\
\text { doutorado }\end{array}$ & $\begin{array}{l}\text { Floriano de } \\
\text { Azevedo } \\
\text { Marques Neto }\end{array}$ \\
\hline $\begin{array}{l}\text { SENA, Fernanda Vick } \\
\text { Soares de }\end{array}$ & 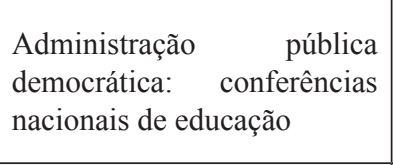 & 2018 & $\begin{array}{l}\text { Dissertação } \\
\text { de mestrado }\end{array}$ & $\begin{array}{l}\text { Gustavo } \\
\text { Henrique } \\
\text { Justino de } \\
\text { Oliveira }\end{array}$ \\
\hline $\begin{array}{l}\text { PIRES, Gabriel Lino } \\
\text { de Paula }\end{array}$ & $\begin{array}{l}\text { O perfil da atuação do } \\
\text { Ministério Público Brasileiro: } \\
\text { os princípios institucionais da } \\
\text { independência funcional, da } \\
\text { unidade e da indivisibilidade } \\
\text { sob a óptica da segurança } \\
\text { jurídica }\end{array}$ & 2018 & $\begin{array}{c}\text { Tese de } \\
\text { doutorado }\end{array}$ & $\begin{array}{l}\text { Fernando Dias } \\
\text { Menezes de } \\
\text { Almeida }\end{array}$ \\
\hline $\begin{array}{l}\text { ENEI, José Virgílio } \\
\text { Lopes }\end{array}$ & $\begin{array}{l}\text { Garantias de adimplemento } \\
\text { da administração pública } \\
\text { ao contratado nas parcerias } \\
\text { público-privadas }\end{array}$ & 2018 & $\begin{array}{l}\text { Tese de } \\
\text { doutorado }\end{array}$ & $\begin{array}{l}\text { Fernando Dias } \\
\text { Menezes de } \\
\text { Almeida }\end{array}$ \\
\hline $\begin{array}{l}\text { LIMA, Mário Márcio } \\
\text { Saadi }\end{array}$ & $\begin{array}{l}\text { O Estado como sócio } \\
\text { minoritário qualificado: o } \\
\text { regime jurídico das empresas } \\
\text { semiestatais }\end{array}$ & 2018 & $\begin{array}{l}\text { Tese de } \\
\text { doutorado }\end{array}$ & $\begin{array}{l}\text { Rodrigo Pagani } \\
\text { de Souza }\end{array}$ \\
\hline $\begin{array}{l}\text { COSTA, Yahn Rainer } \\
\text { Gnecco Marinho da }\end{array}$ & $\begin{array}{l}\text { Delineamentos sobre a } \\
\text { responsabilidade objetiva das } \\
\text { pessoas jurídicas por atos de } \\
\text { corrupção no Brasil }\end{array}$ & 2019 & $\begin{array}{l}\text { Dissertação } \\
\text { de mestrado }\end{array}$ & $\begin{array}{l}\text { Gustavo } \\
\text { Henrique } \\
\text { Justino de } \\
\text { Oliveira }\end{array}$ \\
\hline $\begin{array}{l}\text { BARROS FILHO, } \\
\text { Wilson Accioli de }\end{array}$ & $\begin{array}{l}\text { Acordos administrativos } \\
\text { no âmbito dos precatórios } \\
\text { requisitórios judiciais: um } \\
\text { estudo dos modelos adotados } \\
\text { por entes federados à luz do } \\
\text { consesualismo }\end{array}$ & 2019 & $\begin{array}{l}\text { Dissertação } \\
\text { de mestrado }\end{array}$ & $\begin{array}{l}\text { Gustavo } \\
\text { Henrique } \\
\text { Justino de } \\
\text { Oliveira }\end{array}$ \\
\hline $\begin{array}{l}\text { BARCELOS, Daniel } \\
\text { Ribeiro }\end{array}$ & $\begin{array}{l}\text { Incentivos } \\
\text { whistleblowing: a proteção } \\
\text { do reportante na política } \\
\text { de combate à corrupção no } \\
\text { Brasil }\end{array}$ & 2019 & $\begin{array}{l}\text { Dissertação } \\
\text { de mestrado }\end{array}$ & $\begin{array}{l}\text { Gustavo } \\
\text { Henrique } \\
\text { Justino de } \\
\text { Oliveira }\end{array}$ \\
\hline $\begin{array}{l}\text { NERY, Ana Rita de } \\
\text { Figueiredo }\end{array}$ & $\begin{array}{l}\text { Interações políticas e a ação } \\
\text { da administração pública }\end{array}$ & 2019 & $\begin{array}{c}\text { Tese de } \\
\text { doutorado }\end{array}$ & $\begin{array}{l}\text { Maria Sylvia } \\
\text { Zanella Di } \\
\text { Pietro }\end{array}$ \\
\hline
\end{tabular}




\begin{tabular}{|c|c|c|c|c|}
\hline $\begin{array}{l}\text { JURKSAITIS, } \\
\text { Guilherme Jardim }\end{array}$ & $\begin{array}{l}\text { Equilíbrio econômico- } \\
\text { financeiro em contratos } \\
\text { administrativos }\end{array}$ & 2019 & $\begin{array}{c}\text { Tese de } \\
\text { doutorado }\end{array}$ & $\begin{array}{l}\text { Fernando Dias } \\
\text { Menezes de } \\
\text { Almeida }\end{array}$ \\
\hline $\begin{array}{l}\text { ROTENBERG, Julia } \\
\text { Schulz }\end{array}$ & $\begin{array}{l}\text { A responsabilidade civil da } \\
\text { Administração Pública pela } \\
\text { perda de uma chance }\end{array}$ & 2020 & $\begin{array}{l}\text { Dissertação } \\
\text { de mestrado }\end{array}$ & $\begin{array}{l}\text { Edmir Netto de } \\
\text { Araújo }\end{array}$ \\
\hline ISSA, Rafael Hamze & $\begin{array}{l}\text { O fomento administrativo } \\
\text { e sua implementação por } \\
\text { empresas estatais }\end{array}$ & 2020 & $\begin{array}{c}\text { Tese de } \\
\text { doutorado }\end{array}$ & $\begin{array}{l}\text { Floriano de } \\
\text { Azevedo } \\
\text { Marques Neto }\end{array}$ \\
\hline $\begin{array}{l}\text { VALLE, Kamile } \\
\text { Medeiros do }\end{array}$ & $\begin{array}{l}\text { O controle de resultados no } \\
\text { fomento às organizações da } \\
\text { sociedade civil }\end{array}$ & 2020 & $\begin{array}{l}\text { Dissertação } \\
\text { de mestrado }\end{array}$ & $\begin{array}{l}\text { Floriano de } \\
\text { Azevedo } \\
\text { Marques Neto }\end{array}$ \\
\hline $\begin{array}{l}\text { FERNANDES, Rafel } \\
\text { Pereira }\end{array}$ & $\begin{array}{l}\text { O controle externo pelo } \\
\text { Tribunal de Contas da União } \\
\text { da atividade administrativa } \\
\text { de fomento do BNDES }\end{array}$ & 2020 & $\begin{array}{l}\text { Dissertação } \\
\text { de mestrado }\end{array}$ & $\begin{array}{l}\text { Floriano de } \\
\text { Azevedo } \\
\text { Marques Neto }\end{array}$ \\
\hline LUZIA, Cauê Vecchia & $\begin{array}{l}\text { O dever de proporcionalidade } \\
\text { na aplicação de sanções } \\
\text { administrativas no regime de } \\
\text { contratações públicas }\end{array}$ & 2020 & $\begin{array}{c}\text { Tese de } \\
\text { doutorado }\end{array}$ & $\begin{array}{l}\text { Gustavo } \\
\text { Henrique } \\
\text { Justino de } \\
\text { Oliveira } \\
\end{array}$ \\
\hline $\begin{array}{l}\text { POMBO, Rodrigo } \\
\text { Goulart de Freitas }\end{array}$ & $\begin{array}{l}\text { Contratos públicos na Lei de } \\
\text { Inovação Tecnológica }\end{array}$ & 2020 & $\begin{array}{l}\text { Dissertação } \\
\text { de mestrado }\end{array}$ & $\begin{array}{l}\text { Vitor Rhein } \\
\text { Schirato }\end{array}$ \\
\hline $\begin{array}{l}\text { BORDA, Daniel } \\
\text { Siqueira }\end{array}$ & $\begin{array}{l}\text { O regime de licitação das } \\
\text { empresas estatais na Lei } \\
13.303 / 2016\end{array}$ & 2020 & $\begin{array}{l}\text { Dissertação } \\
\text { de mestrado }\end{array}$ & $\begin{array}{l}\text { Vitor Rhein } \\
\text { Schirato }\end{array}$ \\
\hline $\begin{array}{l}\text { SILVA, Érico Xavier } \\
\text { Desterro e }\end{array}$ & $\begin{array}{l}\text { O controle da eficiência } \\
\text { administrativa pelo Tribunal } \\
\text { de Contas }\end{array}$ & 2020 & $\begin{array}{l}\text { Dissertação } \\
\text { de mestrado }\end{array}$ & $\begin{array}{l}\text { Edmir Netto de } \\
\text { Araújo }\end{array}$ \\
\hline $\begin{array}{l}\text { SILVA, Marco Aurélio } \\
\text { de Barcelos }\end{array}$ & $\begin{array}{l}\text { O mito dos serviços públicos } \\
\text { - publicatio, monopólios e a } \\
\text { regulação estatal da atividade } \\
\text { econômica no Brasil }\end{array}$ & 2020 & $\begin{array}{c}\text { Tese de } \\
\text { doutorado }\end{array}$ & $\begin{array}{l}\text { Floriano de } \\
\text { Azevedo } \\
\text { Marques Neto }\end{array}$ \\
\hline
\end{tabular}




\section{ANEXO 3}

\begin{tabular}{c|c|c|c|c}
$89-96$ & $\mathrm{D}$ & $\%$ & $\mathrm{M}$ & $\%$ \\
\hline Total & 5 & $62,5 \%$ & 3 & 37,5 \\
\hline Adv. Pr. & 4 & $50,0 \%$ & & $0,0 \%$ \\
\hline Proc. & & $0,0 \%$ & 2 & $25,0 \%$ \\
\hline Prom. & & $0,0 \%$ & & $0,0 \%$ \\
\hline Mag. & 1 & $12,5 \%$ & & $0,0 \%$ \\
\hline Assis. & & $0,0 \%$ & & $0,0 \%$ \\
\hline Gov. & & $0,0 \%$ & 1 & $12,5 \%$ \\
\hline Pesq. & & $0,0 \%$ & & $0,0 \%$ \\
\hline
\end{tabular}

\begin{tabular}{c|c|c|c|c} 
97-04 & $\mathrm{D}$ & $\%$ & $\mathrm{M}$ & $\%$ \\
\hline Total & 9 & $45,0 \%$ & 11 & $55,0 \%$ \\
\hline Adv. Pr. & 3 & $15,0 \%$ & 1 & $5,0 \%$ \\
\hline Proc. & 3 & $15,0 \%$ & 6 & $30,0 \%$ \\
\hline Prom. & & $0,0 \%$ & 1 & $5,0 \%$ \\
\hline Mag. & 1 & $5,0 \%$ & 1 & $5,0 \%$ \\
\hline Assis. & & $0,0 \%$ & & $0,0 \%$ \\
\hline Gov. & 2 & $10,0 \%$ & 1 & $5,0 \%$ \\
\hline Pesq. & & $0,0 \%$ & 1 & $5,0 \%$ \\
\hline
\end{tabular}

\begin{tabular}{c|c|c|c|c}
$05-12$ & $\mathrm{D}$ & $\%$ & $\mathrm{M}$ & $\%$ \\
\hline Total & 23 & $47,9 \%$ & 25 & $52,1 \%$ \\
\hline Adv. Pr. & 11 & $22,9 \%$ & 17 & $35,4 \%$ \\
\hline Proc. & 4 & $8,3 \%$ & 3 & $6,3 \%$ \\
\hline Prom. & & $0,0 \%$ & 3 & $6,3 \%$ \\
\hline Mag. & 4 & $8,3 \%$ & & $0,0 \%$ \\
\hline Assis. & & $0,0 \%$ & 1 & $2,1 \%$ \\
\hline Gov. & 2 & $4,2 \%$ & 1 & $2,1 \%$ \\
\hline Pesq. & 2 & $4,2 \%$ & & $0,0 \%$ \\
\hline
\end{tabular}




\begin{tabular}{c|c|c|c|c}
$13-20$ & $\mathrm{D}$ & $\%$ & $\mathrm{M}$ & $\%$ \\
\hline Total & 37 & $38,9 \%$ & 58 & $61,1 \%$ \\
\hline Adv. Pr. & 18 & $18,9 \%$ & 33 & $34,7 \%$ \\
\hline Proc. & 7 & $7,4 \%$ & 6 & $6,3 \%$ \\
\hline Prom. & 3 & $3,2 \%$ & 1 & $1,1 \%$ \\
\hline Mag. & 2 & $2,1 \%$ & 4 & $4,2 \%$ \\
\hline Assis. & 1 & $1,1 \%$ & 2 & $2,1 \%$ \\
\hline Gov. & 4 & $4,2 \%$ & 9 & $9,5 \%$ \\
\hline Def. Pub. & & $0,0 \%$ & 2 & $2,1 \%$ \\
\hline Pesq. & 2 & $2,1 \%$ & 1 & $1,1 \%$ \\
\hline
\end{tabular}

